\title{
The Beginning of the Viking Age in the West
}

\author{
Irene Baug $^{1}$ - Dagfinn Skre ${ }^{2}$ D $\cdot$ Tom Heldal $^{3} \cdot \varnothing_{\text {ystein J. Jansen }}{ }^{4}$
}

Published online: 7 December 2018

(c) The Author(s) 2018

\begin{abstract}
During the Viking Age, Arctic Scandinavia was a source of exquisite furs, down, walrus ivory, and other commodities that met with high demand in England and on the Continent. Hitherto, the earliest firm evidence of this trade has been Ohthere's account c. 890, but in light of this paper's findings, its history may be pushed further back in time. Geological analyses of whetstones retrieved in eighth- to early ninth-century Ribe, south-western Jylland, in present-day western Denmark, demonstrate that the majority were quarried near the aristocratic manor Lade ('loading/storing place') in Trøndelag, present-day central Norway, some $1100 \mathrm{~km}$ by sea to the north. Because of their high numbers and durability, whetstones retrieved in Ribe and other urban sites may be regarded as a proxy for long-distance seaborne trade from the Arctic. The peak in this trade on the threshold of the Viking Age invites a reconsideration of the coinciding and conflicting interests of Scandinavian long-distance traders, kings, and Vikings. It is argued that coalitions and conflicts that arose from these interests, and new constraints and opportunities that emerged for these three types of agents, provide keys to understanding why and where Vikings raided overseas up to the mid-ninth century.
\end{abstract}

Keywords Vikings $\cdot$ Rock provenancing $\cdot$ Seafaring $\cdot$ Arctic commodities $\cdot$ Maritime economy $\cdot$ Early medieval trade

\section{Introduction}

Around AD 800, Scandinavians began setting off on Viking raids across the North Sea, an activity that continued over more than two centuries. Historians and archaeologists have done admirable work in identifying the economic, political, and cultural aspects of Scandinavian societies that were necessary longue-durée conditions for the Viking incursions

Dagfinn Skre

dagfinn.skre@khm.uio.no

1 Department of Archaeology, History, Cultural Studies, and Religion, University of Bergen, P.O. Box 7805, 5020 Bergen, Norway

2 Museum of Cultural History, University of Oslo, P.O. Box 6762, St. Olavs Plass, 0130 Oslo, Norway

3 Geological Survey of Norway, P.O. Box 6315, Torgarden, 7491 Trondheim, Norway

4 The University Museum, University of Bergen, P.O. Box 7800, 5007 Bergen, Norway 
overseas. ${ }^{1}$ However, the immediate causes as to why the Viking raids began there and then remain undiscovered; thus their outbreak and early phase must be considered unexplained (Ashby 2015:100).

Recent scholarship has narrowed the scope of inquiry to cast possible causes in sharper relief against a general backdrop. For instance, several studies have focused on the practice of the bride wealth, whereby a man who wished to marry a woman had to pay a sum to her family. Barrett (2010) and Raffield et al. (2017) have suggested that young men's search for treasure to pay bride wealth led them to pillage overseas. Barrett proposes that an assumed dearth of potential marriage partners in Scandinavia was a result of selective female infanticide, while Raffield and his co-authors propose that the supposed paucity of females was the combined effect of polygyny, concubinage, and social inequality. Sindbæk $(2011,2017)$ considers the influx of Islamic silver as the main driver behind the Viking incursions, and he regards bride wealth as an example of what he holds to be the more general significance in Scandinavia of silver: it was used to establish and maintain social networks over time. Ashby (2015) favours a more general condition: pillaging was motivated by the social capital acquired through fame and glory. A more purely cultural condition is emphasised by Price (2002): the connection between Norse religion and a fatalistic warrior mentality.

It seems likely that more or less all of these cultural and social factors played some role in motivating the Viking raids. Still, these factors are hardly unique to ninth-century Scandinavia. For instance, young men's urge to violently acquire wealth and glory has modest explanatory value since it may be regarded as a given, a generic feature of Germanic pre-state societies throughout the first millennium $\mathrm{AD}^{2}$ The grounds for explaining the timing and location of the early Viking raids must be more precisely historically situated in order to frame the decision of Scandinavian ship commanders to direct young men's violent potential into overseas raiding.

The paucity of evidence regarding the acute constraints and opportunities of Viking-ship commanders of the $780 \mathrm{~s}-850 \mathrm{~s}$ is probably the main reason why, compared to general conditions, the search for immediate causes, or 'trigger factors', has been less intense and successful-Barrett (2010:297) finds the enterprise 'unrealistic'. However, the current surge in provenancing of archaeological materials opens possibilities to produce new evidence on two issues of great relevance: the eighth- to ninth-century production and long-distance trade of commodities from Scandinavia, and the interaction between Scandinavians and Continental and British traders and consumers in the southern North Sea zone and along the English Channel (Fig. 1). ${ }^{3}$ Recently, provenancing of reindeer antler has indicated that trade from the Scandinavian Peninsula, present-day Norway and Sweden, to the southern North Sea zone was already underway in the 780s-90s (Ashby et al. 2015).

In the following, we present results from the provenancing of whetstones, demonstrating that this trade was ongoing since the early eighth century and that traded commodities originated in Arctic Scandinavia. Importantly, the high quantities of whetstones allow us

\footnotetext{
1 For comprehensive surveys of earlier research, see Ashby 2015, Barrett 2010, Simek 2004, and McLeod 2014.

2 Parallels to Viking raiding include Gothic incursions into the Roman Empire in the third to fourth centuries, culminating in the sack of Rome in 410, and fifth to seventh century Saxon piracy in the southern North Sea/English Channel zone (Haywood 1999:75-90; Wood 1983:5).

3 Bjørn Myhre (1993:184) held this issue and area to be pivotal for understanding the beginning of the Viking Age in the west, but lacked evidence that would have allowed for closer investigation.
} 


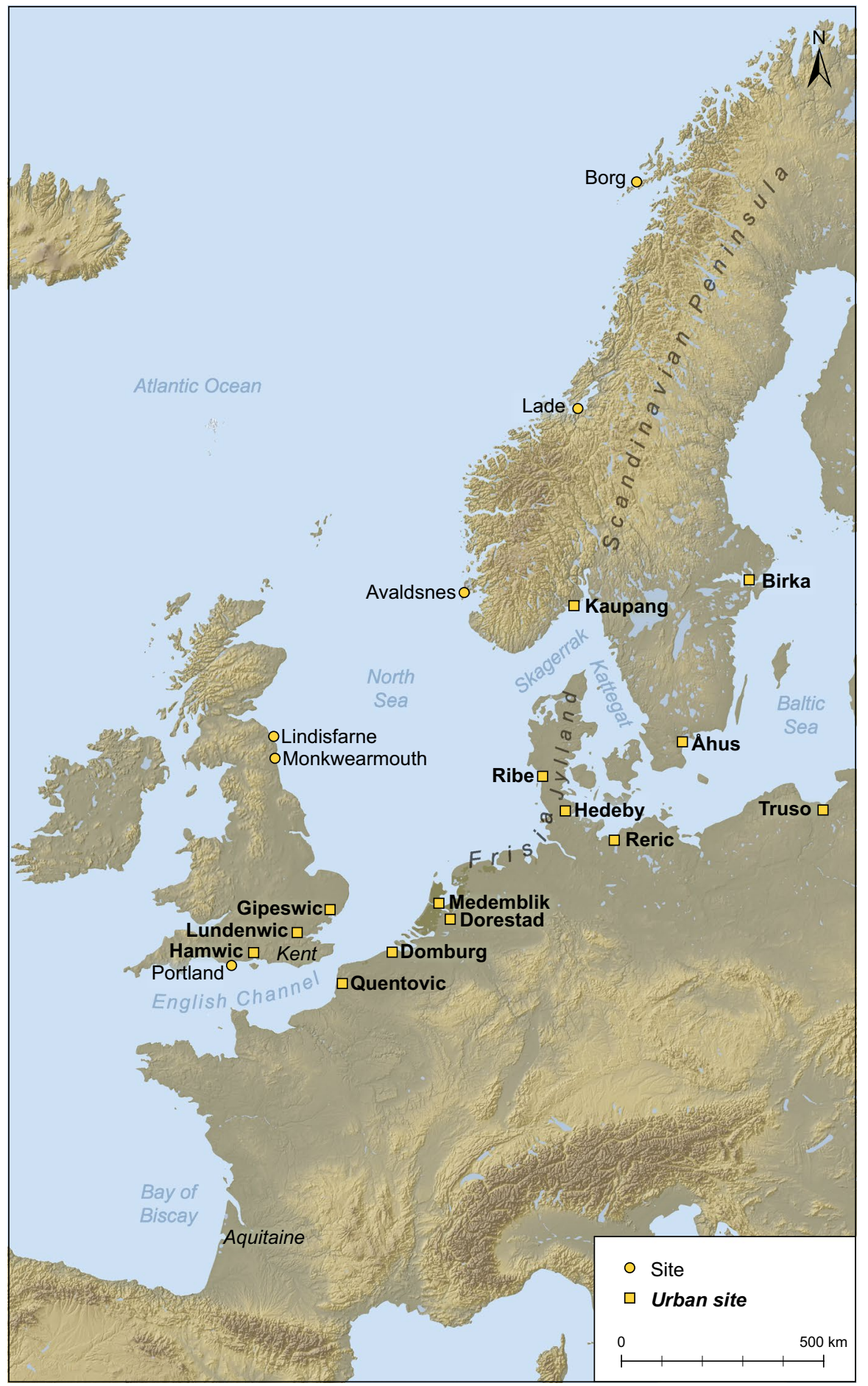

Fig. 1 Scandinavia, the west, and the Baltic. Sites referred to in the text are indicated. Illustration: Ingvild T. Bøckman 
to assess the shifting volume of this long-distance trade through the eighth to mid-ninth centuries.

This evidence, set in the context of the contemporary surge in production and trade around the southern North Sea and English Channel, the early urbanisation in southern Scandinavia and the Baltic (Sindbæk 2011), and the political integration in southern and western Scandinavia, allows us to suggest immediate reasons for why Viking ship commanders turned their activities overseas in the late 700s. The evidence also sheds light on why, after the initial 'scouting phase', raiding in three decades since c. 806 took place predominantly in Ireland and Scotland, and why Vikings in the mid-830s began overwintering overseas and took up raiding in England and the Frankish Empire.

The close connection between raiding and trade that is argued here is based on the fact that the former parasitizes on wealth accumulated through the latter. Trade ventures, particularly over long distances, expose the traders' commodities and proceeds to the danger of piracy. More importantly, the mere threat of piracy in waters, harbours, and production sites tends to subdue production, trade, and consumption, resulting in reduced profits for traders. Thus, conflicting interests between raiders and traders go beyond the direct threat of attacks on traders' ships. In this paper, assessment of the relative strength of the two parties to this conflict, traders and Vikings, and that of their allies, provides a background for discussing changes in volumes and routes of trading and raiding. Such conflicts lend themselves to the agent-oriented approach pursued here. The main characteristic of that approach - to explain decisions through analysis of the agents' constraints and opportunities at the time rather than through their consequences (Gardner 2007:5-8) - assumes particular relevance when analysing situations with uncertain outcomes involving entrepreneurial agency: taking up raiding in new lands, exploring new trade routes, scaling such activities up or down, entering into alliances, or deciding whether to shift from trading to raiding or vice versa.

\section{Scandinavia and the Southern North Sea Zone (Fifth-Ninth Centuries)}

Because of its early date (c. 705-850) and the well-preserved deposits that allow precise dating of artefacts and features (Feveile and Jensen 2000), Ribe (Fig. 1) in the very southwest of Scandinavia is a key site in discussions of the beginning of the Viking Age in the west. Apparently modelled on Frisian sites, it is the north-easternmost of the seventh- to mid-ninth-century seasonal market sites and urban settlements in the southern North Sea/ English Channel zone. While displaying clear Frisian characteristics in the earliest phase, the first few decades show evidence of an increasingly Scandinavian character of metalwork and other artefacts produced at the site. However, most non-regional commodities and raw materials for artisans (glass and copper alloy) appear to have been imported from the west and south (Feveile 2006:30-31). Positioned near the northern end of the area settled by Frisians in the late seventh century (Ellmers 1985:22 and Abb. 2; IJssennagger 2013:88), the site seems intended to facilitate trade between Frisians and people in southern and western Scandinavia.

When the town Kaupang was established c. 800 (Fig. 1), Ribe would have been the most significant harbour among Kaupang's well-testified connections to the southern North Sea zone (Pilø 2011; Skre 2011b; Wamers 2011). Until recently, the earliest commodities produced in the Scandinavian Peninsula found in Ribe were early ninth-century 
soapstone vessels. ${ }^{4}$ However, the beginning of Ribe's northern trade was pushed back to the late eighth century_-before Kaupang's founding_when Ashby et al. (2015) identified ten pieces of reindeer antler among the waste in combmakers' workshops in Ribe phases E-F (780-800). The occurrence of reindeer in Scandinavia is restricted to the woods, highlands, and tundra of the peninsula (Ashby et al. 2015, Fig. 3); evidently, in that period, rather large quantities of reindeer antler were traded to artisans in Ribe as raw material. Additionally, Ashby and his coauthors found indications of even earlier contacts of a different type: two finished reindeer-antler combs, of which fragments were found in phase B (705-25), ${ }^{5}$ probably arrived in Ribe as personal equipment rather than as commodities; the same probably holds for the ship anchor made from iron most likely produced in present-day southern Norway and retrieved in Ribe deposits of a 750-780 date (Ashby et al. 2015:692; Buchwald 2005:296-297). Hence, inhabitants of the peninsula appear to have visited Ribe since the market site's initial decades.

The early eighth-century contacts between the Scandinavian Peninsula and the southern North Sea zone were not a recent development. During the fifth-century migrations and remodelling of communities across the southern North Sea, vast numbers of Roman imports were brought to the west-Scandinavian coast, copper-alloy kettles in particular (Hauken 2005), indicating direct contacts with the Continent. Based on Continental and Insular evidence, Hines (1984:276-278, map 6.1, 1999:230) has pointed to the involvement of west-Scandinavians in the fifth-century Germanic migrations to England, and Nicolay $(2005: 73-79,2017)$ has concluded that people from the Scandinavian Peninsula were involved in the contemporary resettlement of Frisia that followed the near-hiatus in the fourth century (Bazelmans 2009; Bos and Brouwer 2005:25-27; Knol and Ijssennagger 2017:11-12; Krol 2006).

In the mid-sixth century, eastern trade routes from Scandinavia along the Danube, Vistula, and Oder to the Black Sea and the Mediterranean were cut off, probably due to the westward movement of the Avars and the pressure on the Byzantine Empire under Justinian (Ellmers 1985:7-8; Ljungkvist 2009:45). For Scandinavians going south, only the western route across the southern North Sea remained; seventh-eighth-century imports to Scandinavia are predominantly of west-European origin. ${ }^{6}$

In a seminal paper, Jellema (1955) identified Frisians as the main agents in the sixthto seventh-century southern North Sea trade; they extended their activities into the Baltic in the mid-eighth century (IJssennagger 2013; Lebecq 1992, 1999; Näsman 1986:88, 1991:36; Vierck 1983:37-39). Ellmers (1985) calls the Frisian trade of the seventh to eighth centuries the northern peoples' 'umbilical cord' ('Nabelschnur', Ellmers 1985:8) to the south. In this period, says he, Mediterranean and Frankish imports, fashion, and other cultural impulses reached Scandinavia only through Frisian middlemen.

Ellmers seems to somewhat overstate his point. Outside their homelands, Frisians mainly restricted their trade to urban harbours, and there is no evidence that they extended

\footnotetext{
${ }^{4}$ In the ASR 9 excavation there are two fragments in phase G, 800-820, and 22 in phases $\mathrm{H}$ and I, 820-850 (Feveile and Jensen 2006: Fig. 9.12).

${ }^{5}$ Following our inquiry, Ashby has generously supplied additional information on these finds.

${ }^{6}$ Recent analyses of seventh to eighth century glass beads and raw glass indicate that some trade continued between the Mediterranean and the south Baltic (Delvaux 2017 and pers. com.). Some exchange moved via the Danube (Callmer 1991; Curta 2007), while an eastern route, possibly via the Russian river system, brought small amounts of glass from Northern India, some two centuries prior to the much more intense Viking Period trade with the east (Sode et al. 2017). Still, this import is close to negligible compared to that which arrived via the North Sea route.
} 
their trade into Scandinavia before Ribe was established, into the Baltic only when seasonal markets and market sites such as Åhus, Reric, and Truso were established from the mid-eighth century onwards (Callmer 1998; 2007). Before that time, in the seventh century, Scandinavians would have travelled overseas to obtain non-Scandinavian items; predominantly to Dorestad, the town nearest to them. When trading there and possibly also in urban sites further west such as Quentovic, Lundenwic, Gipeswic, and Hamwic, smaller urban sites and beach markets such as Domburg and Medemblik (Fig. 1), Scandinavians would have interacted with Anglo-Saxons, Franks, and others (Wilson 1985:261).

Thus, before the eighth-century establishment of market sites in Jylland and the Baltic, Scandinavians were compelled to undertake long-distance journeys to the Rhine Estuary and beyond to obtain glass vessels, etc. Few apart from aristocrats could provide sufficient manpower and ships for such long-distance travel. This is probably why seventh-century Continental imports to Scandinavia consisted of a relatively narrow scope of commodities of interest to aristocrats. Largely, imports such as glass vessels and garnet jewellery have been retrieved from aristocratic contexts (Arrhenius 1985; Ljungkvist 2009; Näsman 2000). However, more affordable items, in casu glass beads, are quite widespread in modestly equipped graves and in medium-status settlements (Røstad 2016:52-92; Sjøvold 1974; Vinsrygg 1979). Aristocrats probably imported and distributed them within regional networks. Probably, they also imported copper-alloy raw material for their artisans; the regionality of brooch types and their general occurrence in graves (Røstad 2016:307-310; Sjøvold 1974:196-200) suggest that the brooches were produced in Scandinavia and distributed within the same networks as the beads.

In the eighth to early ninth centuries, the non-Scandinavian traders who found their way to urban sites in southern Scandinavia and the Baltic were predominantly Frisians, while Wulfstan's account testifies to the presence of Anglo-Saxons (Jesch 2009). Still, continued trade by Scandinavians in the southern North Sea/English Channel zone is evidenced by a mid-ninthcentury seasoned trader in Vita Anskarii (ch. 27) and by a Frankish bishop who during his flight northwards in 834, probably from the Rhine Estuary, 'found help from certain Northmen who knew the route and the harbours of the sea and the rivers who flow into it' (Nelson 1997:20).

Thus, while commodities in the sixth-seventh-century were brought to and from Scandinavia by Scandinavian traders who obtained them in Dorestad, etc., the eighth to early ninth centuries saw traders of diverse origins bringing goods to towns and markets in southern Scandinavia and the Baltic. In addition to luxuries, they brought cloth and salt of Frisian production, and quernstones, pottery, and other goods from the period's surge in production and trade elsewhere in the Frankish Empire and in the Anglo-Saxon kingdoms. Now, a wide scope of affordable commodities became available for the wider population, because buyers other than aristocrats could make the shorter journey to Scandinavian towns and markets like Birka, Hedeby, and Kaupang.

This development is in line with what Wickham (2008) has found to be a general European trend: aristocratic wealth is necessary for regional economic complexity-commodity production and urban sites - to emerge. Only when markets had been established in the region could the wider population engage in market trade.

Interestingly, the western coast of the Scandinavian Peninsula (Fig. 2) deviates from the south and east in that no market sites or towns appear to have existed in the west before Trondheim was established in the late tenth century. Therefore, unlike in the south and the east, long-distance aristocratic trade there was not supplemented by regional and local trade involving the wider population. In the west, trade retained its character from the seventh century: It was conducted over long distances by aristocrats based along that coast. The results from our 


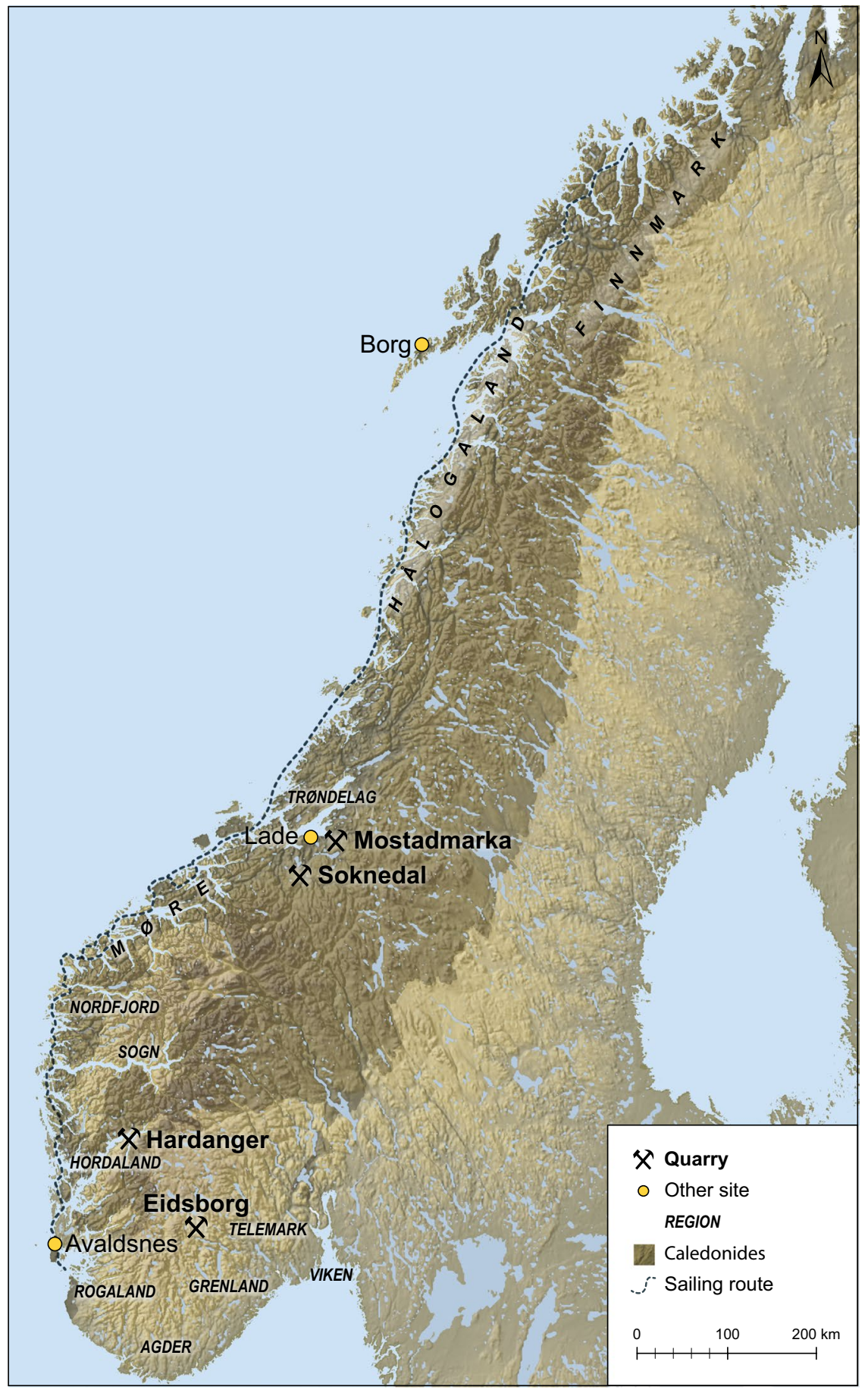

Fig. 2 Regions and sites in western Scandinavia, which in the present context encompasses the Atlantic and North Sea coasts of the Scandinavian Peninsula. The quarries included in the study are indicated. Illustration: Ingvild T. Bøckman 
analysis of Ribe whetstones, presented in the following, provide for the first time a basis for assessing the chronology and volume of west-Scandinavian long-distance trade in this period. This reassessment has ramifications for the understanding of several issues in the early medieval north; of these, the beginning of Viking raiding overseas is the question explored here.

\section{Whetstones in Ribe (c. 705-850)}

Whetstones were among the most important and common tools during the Viking Age; they were a requirement for using knives, axes, needles, arrows, and other tools with a cutting edge or a point. Suitable as raw material for whetstones were rock types containing a small, hard mineral grain, which would serve as an abrasive during whetting (Resi 2011:374).

With its favourable stratigraphy from the eighth century onwards combined with a large and varied artefact material, Ribe stands out as an important site in discussions of the early trade with the western Scandinavian Peninsula. Approximately 1800 whetstone fragments dated to the eighth to thirteenth centuries have been found in Ribe. These are largely fragmented due to heavy wear; the smallest fragments are less than $0.5 \mathrm{~cm}$ long and approx. 1-2 mm thick. Frequent use led to thinning and then breakage; thus, some of the retrieved fragments may have once been part of the same whetstone. Blanks and unused whetstones have not been unearthed in the contexts studied here; such are rarely found in Viking Age settlements (Resi 2011:379).

A total of 446 stones from five different sites in Ribe are included in the study. Altogether 440 of the stones have been retrieved from ASR7 Sct. Nicolajgade 8 and ASR9 Post Office; both sites date to c. 705-850 and were selected for their long date range, high chronological resolution, and high number of whetstones. The small size of the fragments posed a difficulty: the geological analyses used in the study require a minimum of $10 \mathrm{~g}$. Most of the fragments were smaller and not suitable for analysis. Therefore, three fragments found in reliable contexts dated to 720-800 from the site ASR 4M75 Kunstmuseets Have, one fragment from ASR 5M74 Dommerhaven and two fragments dated to the eleventh to thirteenth centuries from ASR 13 Torvet 13-15 were also included in the study.

\section{Research History}

Earlier studies have indicated that material for whetstones in Northern Europe during the Viking Age frequently were sourced from the territory of present-day Norway (e.g. Askvik 1990, 2008; Crosby and Mitchell 1987; Ellis 1969; Hald 1991; Mitchell and Askvik 1984; Myrvoll 1991; Resi 1990, 2008, 2011). These studies, however, have been constrained by the fact that only one type of whetstone could be assigned to a quarry site or region. Whetstones of light-grey, fine-grained muscovite quartz schist are considered to stem from the quarries in Eidsborg in Telemark (Fig. 2). This rock type is here referred to as light-grey schist. The Eidsborg schist belongs lithostratigraphically to the Eidsborg Formation, the uppermost formation in the Bandak Group of the Proterozoic Telemark Supergroup (Oftedahl 1980). The proposed Eidsborg provenance of whetstones of light-grey schist is based on the fact that the area encompasses numerous whetstone quarries with evidence for a long history of production, and on the radiometric dating ( $\mathrm{K}-\mathrm{Ar}$ ) of mica, displaying a cooling age between 900 and 950 million years, rather typical of the Precambrian rocks in this region (Mitchell and Askvik 1984). Macroscopic identification and microscopic studies of thin sections on whetstones of light-grey schist from Kaupang, Hedeby, Wolin, 
Aggersborg, Ribe, and various sites on the British Isles have demonstrated their origin in Eidsborg (Askvik 1990, 2008, 2014; Crosby and Mitchell 1987; Hald 1991; Mitchell and Askvik 1984; Moore 1978; Resi 2011).

A second type of schist considered to have originated in the western Scandinavian Peninsula is a more fine-grained schist that has been referred to under slightly varying terminology, such as muscovite-biotite-quartz-phyllite (Ellis 1969), blue phyllite (Moore 1978), bluish-grey to dark grey phyllite (Kars 1983), dark, blue-purple phyllite (Gaunt 2000; Moore 1983), dark grey, very fine-grained muscovite-quartz schist (Askvik 1990, 2008; Mitchell and Askvik 1984), purple phyllite (Crosby and Mitchell 1987), and metasiltstones (Hald 1991). We find the terminology very fine-grained muscovite-quartz schist used by Mitchell and Askvik (1984) and Askvik (1990, 2008) to be the most precise, and is here shortened to very fine-grained schist. Such whetstones from Ribe vary from dark grey to purple in colour. Radiometric dating $(\mathrm{K}-\mathrm{Ar})$ of whetstones have dated this rock type to between $403 \pm 10$ and $446 \pm 7$ million years (cooling age for mica), coinciding with the late phase of the Caledonian Orogeny (Mitchell et al. 1984). The Caledonides in Europe occur in a belt crossing Scandinavia, England, Scotland, and Ireland, as well as in a zone in central Europe. In the latter zone, the Caledonian rocks are covered by post-Caledonian deformation, meaning that a central European origin of Caledonian whetstones can be excluded (Askvik 2008:8). England is not a likely source area due to the relatively small numbers of whetstones of the Caledonian type found there (Crosby and Mitchell 1987:498). Greenland can be excluded as a possible source because of the early date of the Caledonian whetstones; they predate the eleventh century colonisation of Greenland. Scotland and Shetland have been suggested as a possible origin; however, the Shetland schist is more coarsely grained than the Caledonian whetstones discussed here (Crosby and Mitchell 1987:501). Therefore, a Scandinavian provenance seems plausible, where the Caledonian belt covers the approx. $1700 \mathrm{~km}$ of the western Scandinavian Peninsula from Rogaland to the North Cape (Fig. 2; Askvik 2008:8; Mitchell and Askvik 1984). Yet, the whetstones' provenance within this area has until now remained unconfirmed. This type of whetstone is common at the same Viking Age sites in Northern Europe where Eidsborg whetstones are found.

The first study of whetstones from Ribe, conducted by archaeologist Siri Myrvoll and geologist Niels Hald in 1991, included a total of 117 whetstones from excavations during 1970-6. Based on macroscopic identification and thin sections, Myrvoll and Hald identified several petrographic groups, such as grey schist, siltstones, sandstones, and miscellaneous (Hald 1991; Myrvoll 1991), indicating a variety of origins. They also identified whetstones of both the light-grey schist and the very fine-grained schist. The former were identified as whetstones from Eidsborg; 17 of the pieces examined by Myrvoll and Hald, 14.5\%, are of this type. Based on datings of the find contexts, Myrvoll concluded that the distribution of whetstones from Eidsborg began in the ninth century (Hald 1991; Myrvoll 1991:117, 121, 129).

The very fine-grained schist-Myrvoll and Hald termed it metasiltstone-was their largest group of whetstones, consisting of 61 pieces $(51 \%)$. The stones have fairly variable colour nuances: they considered whetstones with a purple colour to share a common provenance, whereas stones with a grey colour were thought to represent a different group (Hald 1991:143; Myrvoll 1991:119). This delineation was not firmly established, and the provenance of the whetstones could not be identified beyond a possible origin in the Scandinavian Caledonian belt (Hald 1991; Myrvoll 1991:129).

Shortly thereafter, the 'Post Office excavation' in Ribe during 1990-1 produced a chronological breakthrough and a solid base for absolute dating from the period 705-850, and thus new possibilities regarding the chronology of whetstones. 


\section{Narrowing the Search}

Left with a huge area covered by Caledonian rocks, a strategy for narrowing the search for the unknown source for the very fine-grained schist was needed. The cooling ages alone give us a large window of opportunities, and it is not a viable strategy to blindly follow that line of research. Firstly, based on the arguments above, we assumed that the source is within the Norwegian Caledonides, and we considered that there are good enough reasons for present-day Norway being the first area to search. Secondly, due to the grain-size and metamorphic grade of the schist (low-grade) we assumed that the source must be within the low-grade metamorphic parts of the Norwegian Caledonides. Thirdly, we assumed that a quarry site of such potential importance would have been used at later stages in history, and would be known. These assumptions lead to the following strategy of research:

- Review of known whetstone quarry sites (Geological Survey of Norway database: http://geo.ngu.no/kart/mineralressurser/)

- Comparing visual appearance, lithology and cooling ages

The review is summarised in Table 1, where two areas (Mostadmarka and Soknedal, both in Trøndelag) seemed to represent the best match. It is interesting to note that both these quarry areas are situated in the same geological unit-the Støren Nappe. This unit also contains schist formations at Stjørdal, about $15 \mathrm{~km}$ NNE to Heingruva, sharing similar cooling history/ages. The Stjørdal schists were actually discussed as a potential source to the "Caledonian whetstone" by Crosby and Mitchell (1987).

Given that we established a hypothesis that the quarry sites in the Mostadmarka area (20-25 km ESE of Trondheim) and the Soknedal area (50 km SSW of Trondheim) were the most likely candidates for a source, the next step was to confirm or reject the hypothesis by conducting geochemical and petrographical analyses. In addition to the quarries in question within the two quarry areas, we added similar analyses for some of the less likely candidates, for the sake of visualising petrographic and geochemical contrasts. Thus, the data from the four quarries were compared with data from the Arekoll and the Eidsborg quarries. The latter was included also for confirming or rejecting that Eidsborg really was the source for the light grey schist in Ribe, and thus also for providing further evidence of the viability of the chosen methods.

\section{Methodology}

In total, 11 quarries are included in this study and compared with whetstones from Ribe: two quarries in Mostadmarka (Rollset and Heingruva) and two quarries in Soknedal (Skjeftli and Sørlifjell) in the Trøndelag region, six quarries in Eidsborg in Telemark (Jar, Storeufs, Lofthus, Steinbergnut, Gunnheim and Berg) and one quarry in Hardanger in Hordaland (Årekoll) (Fig. 2). The six quarries in Eidsborg bear traces of large-scale, long-term production, in part due to their size and extent, and all are considered as possible sources for the Ribe whetstones. The two quarries in Mostadmarka are located at a distance of $8 \mathrm{~km}$ from each other (Fig. 3). The size of the Heingruva quarry indicates a large-scale production, most likely intended as surplus, whereas both the Soknedal 


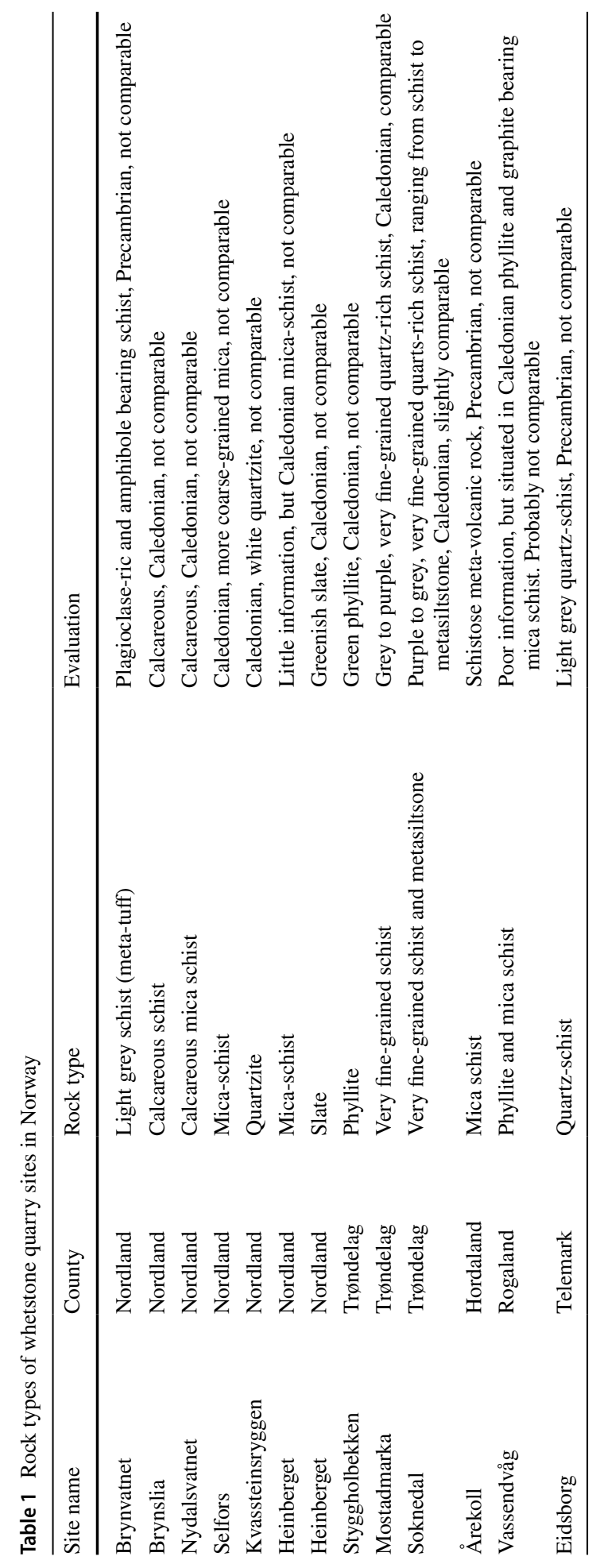




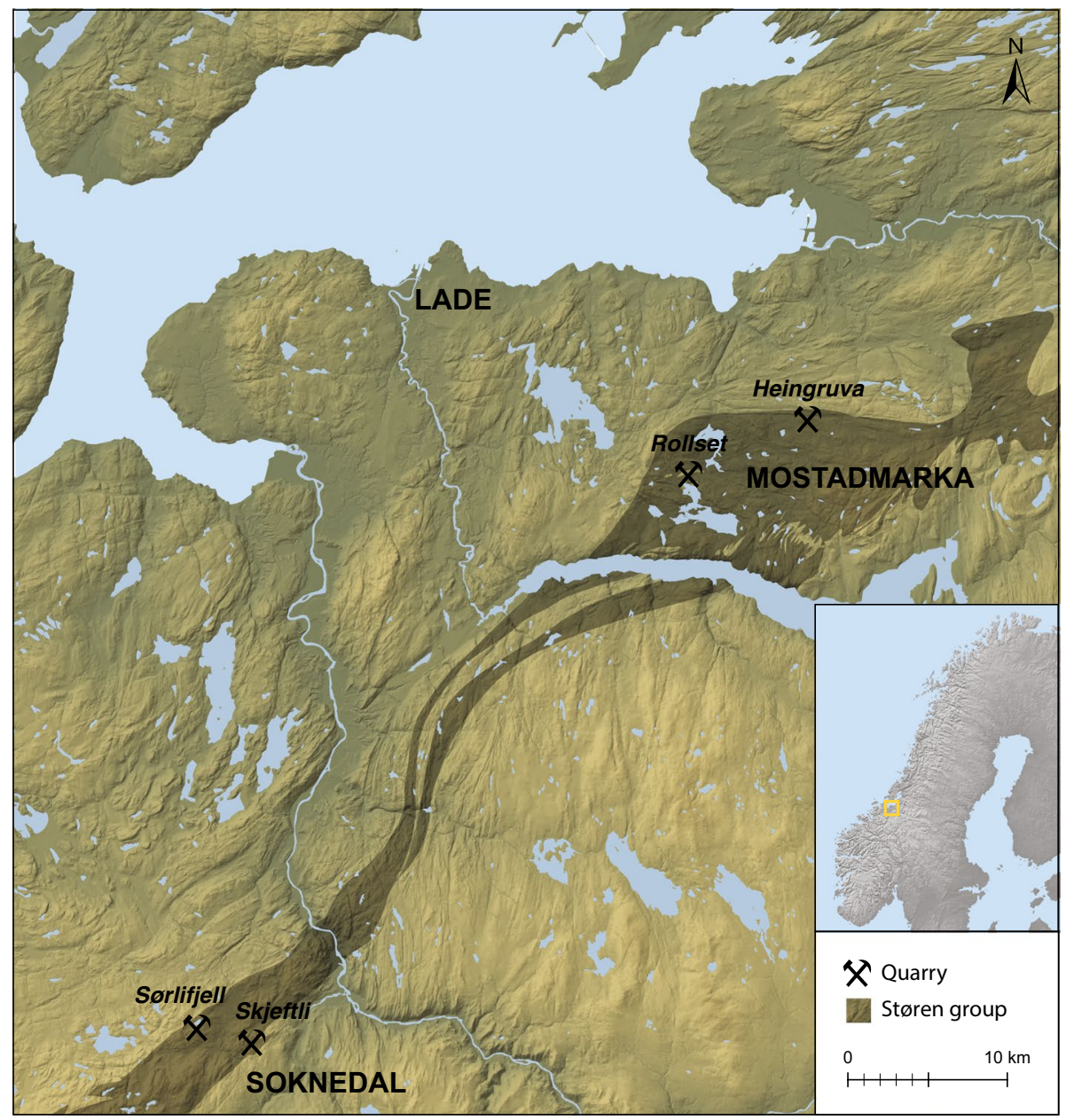

Fig. 3 The Mostadmarka and Soknedal quarries within the Støren Nappe in the Caledonian Nappe sequence. The rock that is quarried for whetstones occurs as thin inliers within largely volcanic rocks. Illustration: Ingvild T. Bøckman

quarries are rather small. The Rollset quarry is difficult to evaluate, since it is partly covered by vegetation. Undiscovered quarries in the area are expected to be found within the same unit (Fig. 3). The Årekoll quarry in Hardanger that supplied whetstones of fine grained quartz mica schist is known from the early nineteenth century, but may be older. The quarry has not been studied in detail, but a geological description, including a thin section study, has been carried out (Jansen 2001).

The analysis proceeded along following five steps:

1. Visual characterisation of whetstones from Ribe (446 pieces) on site in order to identify whetstones with a possible provenance within present-day Norway

2. Visual characterisation and microscopic study on site in Ribe of whetstones with a possible provenance in present-day Norway, and dividing the objects into three lithological groups (306 pieces, Table 2) 
3. Collection of representative samples from these lithological groups (21 pieces)

4. Petrographic analyses (of thin sections) of a selection of samples from Ribe and quarry sites (11 pieces from Ribe chosen from the 21 pieces in step 3, Table 2; compared with 16 samples from 11 quarries in Table 1)

5. Various geochemical whole-rock analyses of selections of samples from Ribe and quarry sites (14 pieces from Ribe chosen from the 21 pieces in step 3, Table 2, compared with 60 reference samples from 11 quarries in Table 1. Four of these 14 pieces overlap with the 11 Ribe pieces chosen in step 4)

Due to practical limitations, it was not possible to run the same analytical procedure for all samples from Ribe. The small size of many of the samples was a constraint, especially for the geochemical whole-rock analyses; thus, not all the samples used for the petrographic analysis were suitable for geochemical analyses. However, samples for both the petrographic and the geochemical analyses were selected from all three lithological groups (Table 2). Because petrographic and geochemical analyses both largely confirmed the integrity of the groups established through visual characterisation and microscopic study, we consider the number of samples analysed in the two final steps sufficient to provide reliable results. Analyses were carried out by the Geological Survey of Norway (NGU).

\section{On-site Visual Examination}

In step 2, 306 items with an assumed west-Scandinavian origin were divided into the three lithological groups seen in Table 2.

\section{Petrographic Examination and Thin Sections}

Thin sections were made from 11 whetstones from two sites in Ribe dating from the eighth century: two of light-grey schist, eight of very fine-grained schist (one of which was of a dark variety and more coarse-grained compared to the 'typical' very fine-grained schist), and one biotite schist.

Not surprisingly, from comparing the 11 samples to samples from quarries in Table 1, the whetstone sample of light-grey schist type has a petrography similar to that of the quarries in Eidsborg. The petrographic examination also suggests a strong match between the very finegrained schist in Ribe and that of the Mostadmarka quarries in Trøndelag (Heingruva and Rollset). Both visually and in thin section, the eight whetstones of very fine-grained schistincluding the more coarse-grained and darker fragment- turned out to be indistinguishable

Table 2 Lithological groups with a possible provenance within present-day Norway, and number of analyses carried out from the different groups

\begin{tabular}{lccc}
\hline & $\begin{array}{l}\text { Total number of } \\
\text { fragments }\end{array}$ & $\begin{array}{l}\text { Petrographic analyses } \\
\text { of thin section }\end{array}$ & $\begin{array}{l}\text { Geochemical } \\
\text { whole-rock } \\
\text { analyses }\end{array}$ \\
\hline $\begin{array}{l}\text { Light-grey schist (assumed Eidsborg) } \\
\begin{array}{l}\text { Very fine-grained schist (assumed Mostad- } \\
\text { marka or Soknedal) }\end{array}\end{array}$ & 233 & 1 & 3 \\
$\begin{array}{l}\text { Biotite schist (assumed unknown origin) } \\
\text { Total }\end{array}$ & 34 & 8 & 9 \\
\hline
\end{tabular}



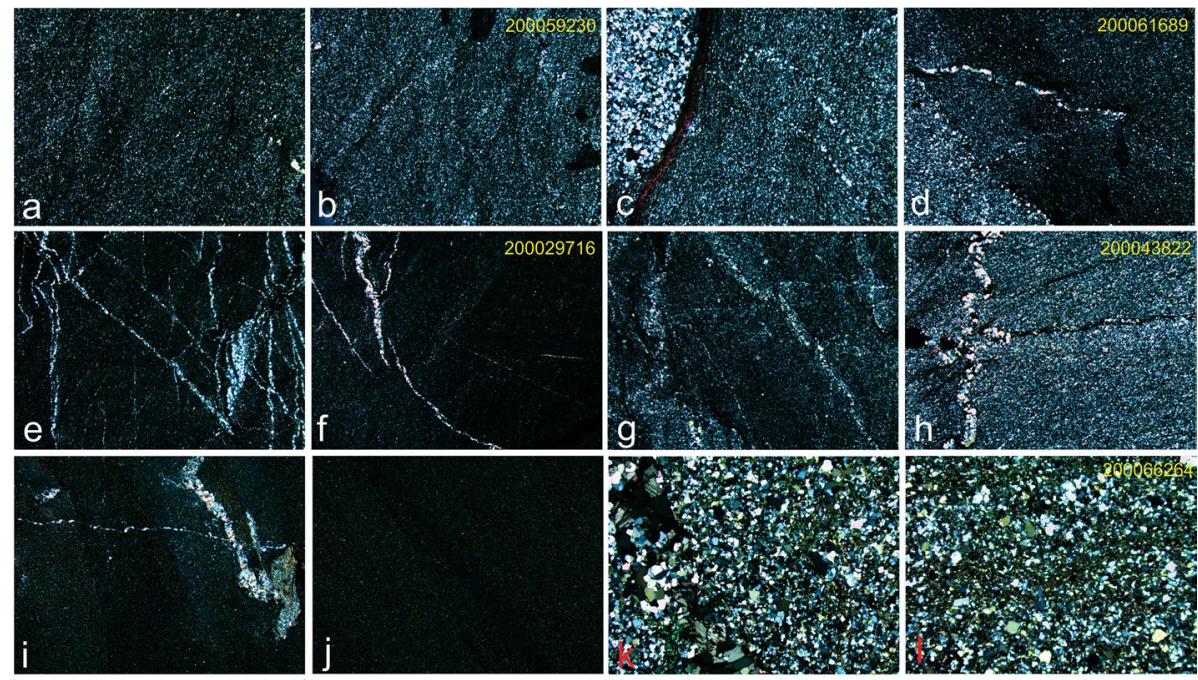

$1,9 \mathrm{~mm}$

Fig. 4 Thin section analyses, examples (crossed polarizers). Sample numbers from Ribe are given on top right corner. a Heingruva quarry, Mostadmarka; b sample from Ribe, similar to (a); c Heingruva quarry, Mostadmarka; d sample from Ribe, similar to (c); e Rollset quarry, Mostadmarka; f sample from Ribe, similar to (e); g Rollset quarry, Mostadmarka; h sample from Ribe, similar to (g); i Skjeftli quarry, Soknedal, $\mathbf{j}$ Sørlifjell quarry, Soknedal; k Jar quarry, Telemark; l sample from Ribe, similar to (k). Photos: Tom Heldal

from the samples collected at the two quarries (Fig. 4). To date, no other whetstone quarry displaying the same geological characteristics has been found in the Scandinavian Peninsula. The rocks in question are not common constituents in the Caledonian bedrock in Scandinavia. Although the possibility remains that similar lithologies might yet be identified elsewhere in the Trøndelag region and in the south-western part of Hordaland, there is little likelihood of finding such rocks containing undiscovered whetstone quarries (Fig. 2). The two quarries in Mostadmarka, however, share a similar geology, complicating attempts to distinguish them from each other. A sample from the third group from the on-site visual examination, biotite schist (ASR $9 \times 311$ ), could not be matched with any of the quarry-site samples; the provenance for this group remains unknown. One pinkish fine-grained fragment, (ASR $9 \times 400$ id 200057107) also came out with an unknown provenance (Table 3).

\section{Geochemical Whole-Rock Analyses: Major Element Analyses by XRF}

Fourteen samples from Ribe (Table 2) were analysed by XRF on major elements at NGU laboratories (PANalytical Axios $4 \mathrm{~kW} \mathrm{XRF}$ ). Nine of the samples were of the very finegrained schist, three were of light grey schist (assumed Eidsborg), and two were biotite schist. These were compared to a total of 60 samples from the quarries selected for comparison (see above).

In Fig. 5a-c the Ribe samples are plotted against groups of quarries in various combinations of $\mathrm{Al}_{2} \mathrm{O}_{3}, \mathrm{MgO}, \mathrm{Fe}_{2} \mathrm{O}_{3}, \mathrm{SiO}_{2}, \mathrm{TiO}_{2}$, and $\mathrm{MnO}$. The results are rather conclusive: the quarries are separated into distinct clusters; samples assumed to originate from Eidsborg quarries (light-grey schist) plot within the Eidsborg quarries cluster, whereas samples assumed to originate from the Mostadmarka quarries (very fine-grained schist) plot 
Table 3 Thin sections of 11 whetstones from Ribe compared with quarries in present-day Norway

\begin{tabular}{lllll}
\hline ID no. & $\begin{array}{l}\text { Mostadmarka (Heingruva } \\
\text { and Rollset) }\end{array}$ & Skjeftli & Sørlifjell & Eidsborg \\
\hline ASR 4M75 D9435 & 5 & 2 & 0 & 0 \\
ASR 4 M75 D12186 & 4 & 3 & 0 & 0 \\
ASR $9 \times 400$ id 200057107 & 1 & 1 & 0 & 0 \\
ASR $9 \times 329$ & 4 & 1 & 0 & 0 \\
ASR $9 \times 395$ & 5 & 0 & 0 & 0 \\
ASR $9 \times 156$ & 4 & 0 & 0 & 0 \\
ASR $9 \times 311$ & 0 & 0 & 0 & 0 \\
ASR $9 \times 261$ & 4 & 2 & 0 & 0 \\
ASR $9 \times 388$ & 4 & 1 & 0 & 0 \\
ASR $9 \times 392$ & 5 & 1 & 0 & 0 \\
ASR $9 \times 363$ & 0 & 0 & 0 & 5 \\
\hline
\end{tabular}

$0=$ no match, $1=$ poor match, 4 and $5=\operatorname{good}$ and excellent match indicating provenance. Whetstones with no match or a poor match come from an unknown source

within the Mostadmarka cluster. Notwithstanding the possibility of additional, undiscovered sources discussed above, the XRF analyses indicate with reasonably high confidence that the very fine-grained schist from Ribe was quarried in the Mostadmarka area.

The two biotite samples do not fit into any of the quarries; they both show deviating geochemistry in at least one of the three plots. It is therefore reasonable to conclude that they have their origin somewhere other than the sampled quarries.

Considerable overlap among major-element plots of samples from the two quarries in Mostamarka precludes determining whether the Ribe whetstones originate either from one of the quarries exclusively, or from both.

\section{Results}

As suspected, whetstones of light-grey schist most likely originate from the quarries in Eidsborg. Likewise, the present study demonstrates with a high level of confidence that whetstones of very fine-grained schist from Ribe were quarried in the Mostadmarka area in Trøndelag (Table 4). We suspect that these results also apply for whetstones in varieties of this latter type of schist found in other eighth to eleventh century sites in Scandinavia and the North Sea zone. Although we cannot fully exclude the possibility of undiscovered quarries, we consider it highly probable that whetstones of very fine-grained schist from Ribe were quarried in Mostadmarka. The schist in the Mostadmarka quarries displays distinct colour nuances, and whetstones with both purple and grey colours seem to have been extracted here. We also suspect that there are several additional, undiscovered quarry sites of this rock type within the Mostadmarka area, particularly in the vicinity of Heingruva and Rollset. These results open several avenues of future research: further development of methodology to obtain more exact provenance, analyses of whetstones from other sites in Norway, and more detailed investigations of the quarries in Mostadmarka.

Our study thus indicates that quarries within two large production sites within presentday Norway, Eidsborg and Mostadmarka, were major suppliers of whetstones to Ribe. 
Fig. 5 a Ribe samples plotted against groups of quarries. $\mathrm{Al}_{2} \mathrm{O}_{3}$ versus $\mathrm{MgO}$ define two distinct trends; one following the Mostadmarka and the Soknedal quarries, and one defined by the Telemark quarries. Further to the right is the Hardanger quarry. The very fine-grained schist from Ribe plots clearly within the Mostadmarka quarries, except for one sample that also fits with the Soknedal quarries. Light grey schist from Ribe is clustered within the samples from the Telemark quarries, while the two biotite schist samples do not fit any of the quarry areas. Illustration: Tom Heldal, Ingvild T. Bøckman. b Ribe samples plotted against groups of quarries. Ratio diagram showing basically the same pattern as (a), but here the separation between the Mostadmarka/Soknedal quarries and the Telemark quarries/Hardanger quarry is much clearer. Moreover, one of the biotite schists plots clearly outside the quarry areas. Illustration: Tom Heldal, Ingvild T. Bøckman. c Ribe samples plotted against groups of quarries. $\mathrm{SiO}_{2}$ versus $\mathrm{MnO}$, showing that all the Ribe samples of very fine-grained schist plot within the Mostadmarka cluster, and none within the Soknedal cluster. Note that the Ribe light grey schist are confined entirely to the Telemark quarry cluster. Illustration: Tom Heldal, Ingvild T. Bøckman

In Mostadmarka, the size of the quarry Heingruva is indicative of large-scale production. Quarrying here is known to have taken place in the 1600s, with some suggestion that it was used in the nineteenth and twentieth centuries (Bakmark and Rø 2014; http://geo. ngu.no/kart/mineralressurser/). Today, the quarry is present as a wide shaft of $15 \times 30 \mathrm{~m}$ filled with water, with an estimated depth between 5 and $15 \mathrm{~m}$. The bedrock is visible as a semi-circle around the waterhole, entering into the spoil-heap to the west (Fig. 6). Traces from quarrying — both quarried rock as well as spoil-are visible in an area approx. $200 \mathrm{~m}$ west of the water (Fig. 7). The Rolset quarry is a small quarry located in a sloping, quite overgrown area with the quarried rock stretching in an east-west direction. Because of the dense vegetation, neither extraction traces nor the spoil-heaps are easy to identify. Within this area, another quarry is known to have been in use in the twentieth century, and the area probably display a number of small quarries hidden under the vegetation.

\section{Chronological Distribution of the Ribe Whetstones}

The site ASR 7 is considered to represent the oldest part of Ribe. Deposits and finds from ASR 7 begin c. 705 and come to an end c. 795, not because activities ended, but because more recent deposits, except for the context G2, have been truncated (Feveile 2006:40). A total of 107 fragments of whetstones were found during the excavation. Only whetstones from reliable datable contexts are included in this study (89 pieces), comprising finds from the workshop-sequences VH1 to VH6, and the 'Øverste skelgrøft' G2 (Table 5) (Frandsen and Jensen 2006:18).

Nearly half of the whetstones dated to 710-850 (47\%) are assumed to have an origin in Eidsborg or Mostadmarka. Only one of 11 whetstones from pre-760 is west-Scandinavian, increasing to more than half of the material post-760. Only four whetstones date between 795 and 850; three of them originate from the quarries in Mostadmarka. In total, whetstones from Mostadmarka are over four times as common as Eidsborg stones.

The site ASR 9 Post Office comprises approx. 100 square meters, and was excavated 1990-1. The stratigraphy allowed the definition of phases that could be dated within narrow timeframes based on dendrochronology and artefacts. (Feveile and Jensen 2006:119, 24-29). A total of 411 whetstones were retrieved during the excavation, but only 


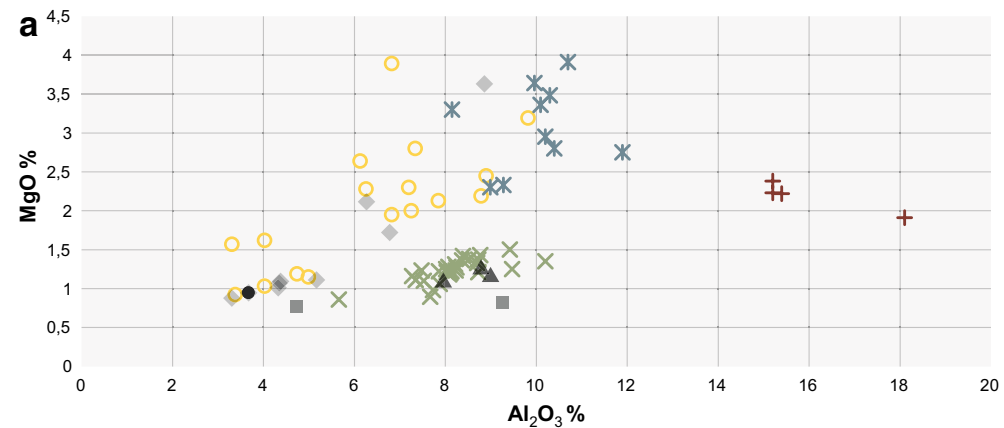

Ribe samples:

Ribe very fine-grained schist

Quarry samples:

- Ribe biotite schist

$\times$ Telemark quarries

$\Delta$ Ribe light grey schist

+ Hardanger quarry

- Ribe dark schist

* Soknedal quarries

- Mostadmarka quarries

b

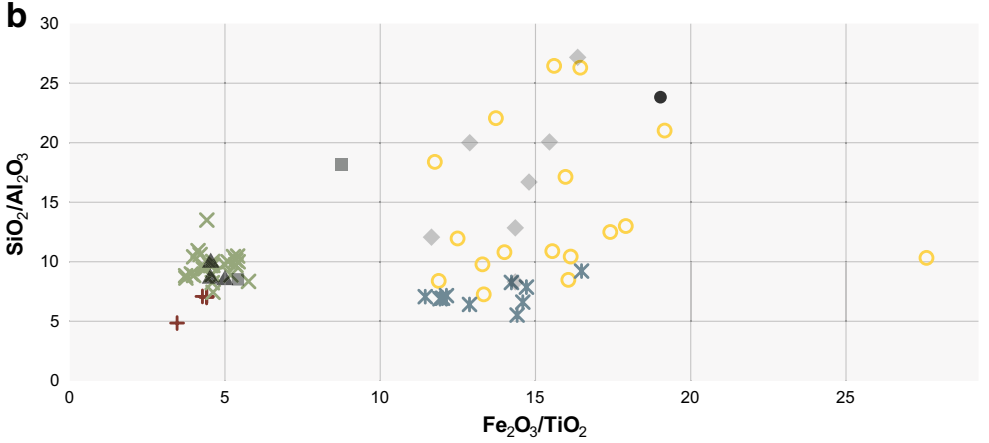

Ribe samples:

Ribe very fine-grained schist

Quarry samples:

- Ribe biotite schist

$\times$ Telemark quarries

$\Delta$ Ribe light grey schist

+ Hardanger quarry

- Ribe dark schist

* Soknedal quarries

- Mostadmarka quarries

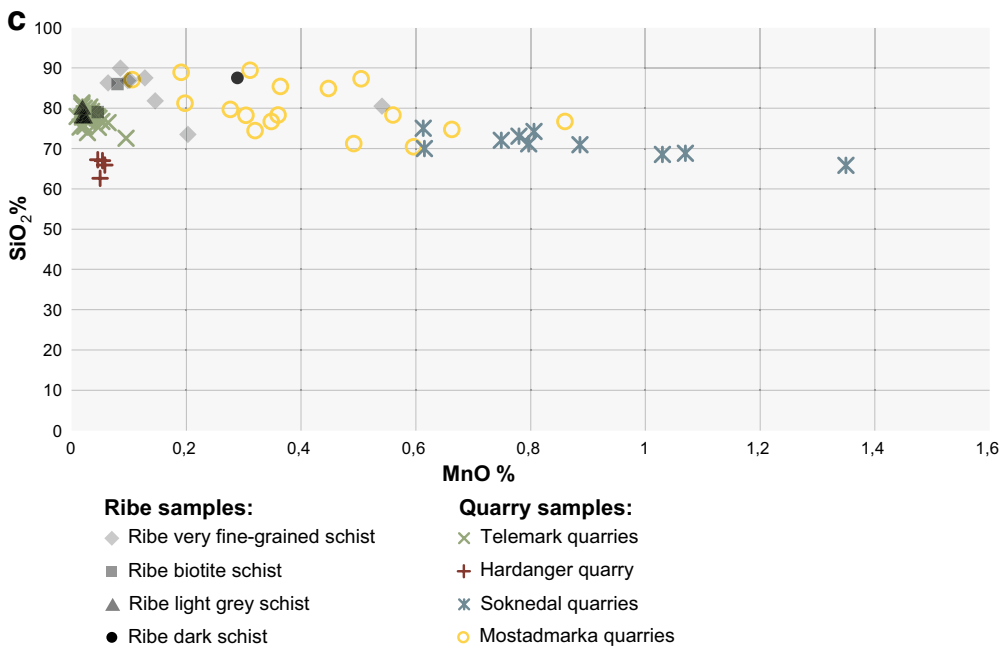




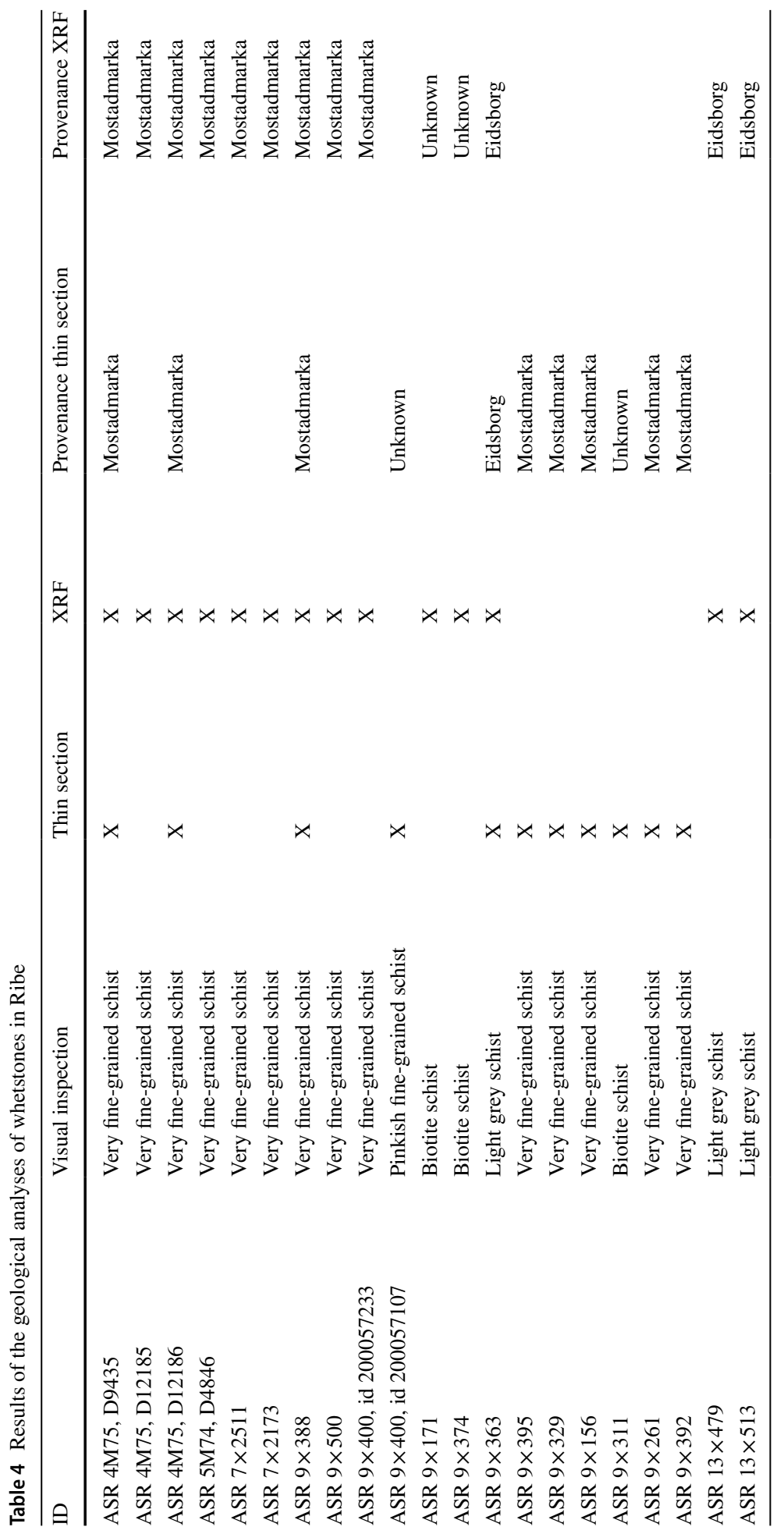




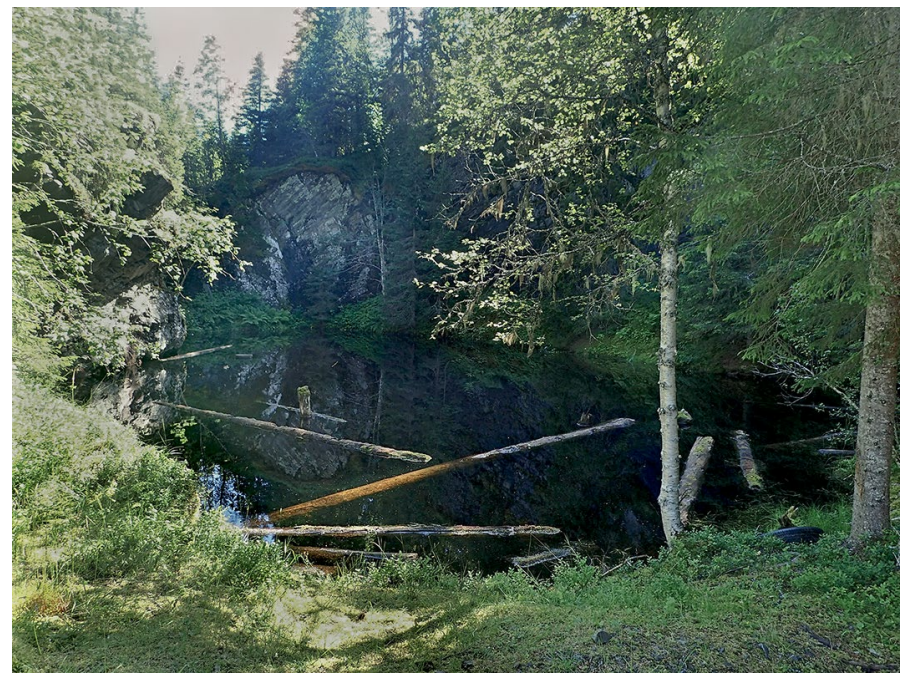

Fig. 6 The Heingruva quarry in Mostadmarka. Photo: Irene Baug

Fig. 7 Spoil heaps from whetstone quarrying at Heingruva. Photo: Irene Baug

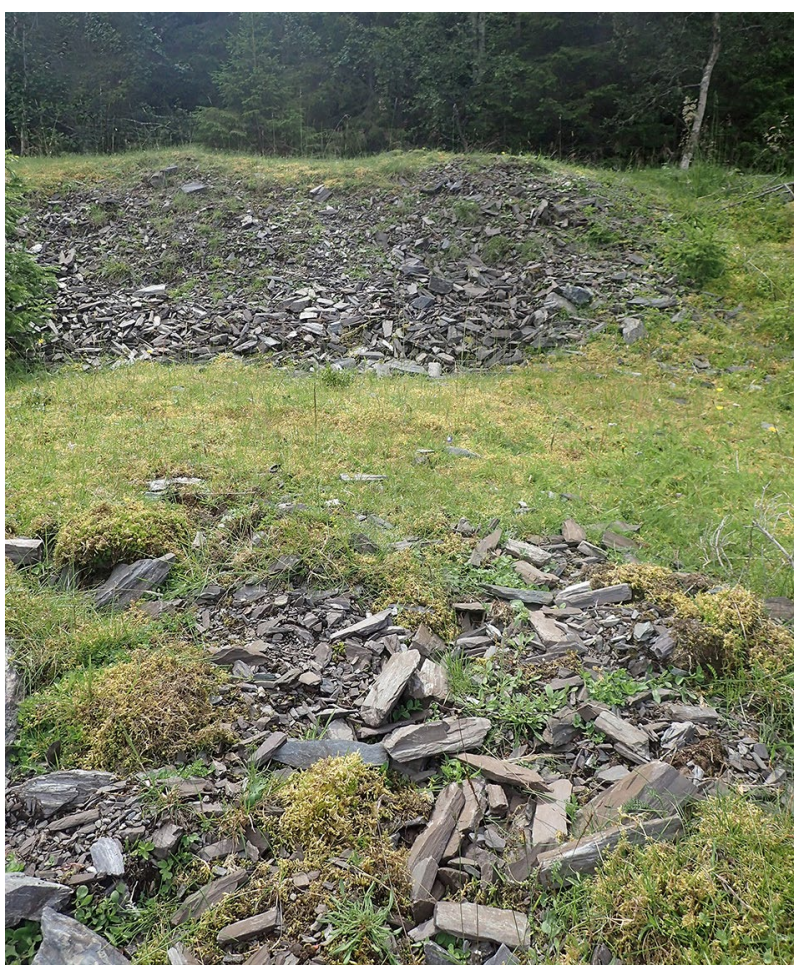


Table 5 Whetstones from ASR 7 Sct. Nicolajgade assumed to originate from Eidsborg and Mostadmarka

\begin{tabular}{lccccccc}
\hline Ribe phase & Date AD & Total number & Eidsborg & $\begin{array}{l}\text { Possible } \\
\text { eidsborg }\end{array}$ & Mostadmarka & $\begin{array}{l}\text { Possible } \\
\text { mostad- } \\
\text { marka }\end{array}$ & $\begin{array}{l}\text { \% of west- } \\
\text { Scandinavian } \\
\text { stones }\end{array}$ \\
\hline G1+ VH1 & $710-725$ & 8 & 0 & 0 & 1 & 0 & 13 \\
VH2 & $725-760$ & 3 & 0 & 0 & 0 & 0 & 0 \\
VH3-6+ VH2a & $760-795$ & 74 & 3 & 5 & 29 & 1 & 51 \\
G2 & $795-850$ & 4 & 0 & 0 & 3 & 0 & 75 \\
G1 + VH1 to & $710-850$ & 89 & 3 & 5 & 33 & 1 & 47 \\
G2 & & & & & & & \\
\hline
\end{tabular}

Table 6 Whetstones from ASR 9 Post Office assumed to originate from Eidsborg and Mostadmarka

\begin{tabular}{lccccccc}
\hline Ribe phase & Date AD & Total number & Eidsborg & $\begin{array}{l}\text { Possible } \\
\text { eidsborg }\end{array}$ & Mostadmarka & $\begin{array}{l}\text { Possible } \\
\text { mostad- } \\
\text { marka }\end{array}$ & $\begin{array}{l}\text { \% of west-Scan- } \\
\text { dinavian stones }\end{array}$ \\
\hline B & $705-725$ & 6 & 0 & 0 & 0 & 2 & 33 \\
C & $725-760$ & 33 & 2 & 0 & 12 & 0 & 42 \\
D & $760-780$ & 34 & 1 & 0 & $14+4$ & 0 & 56 \\
E & $780-790$ & 33 & 1 & 0 & $11+2$ & 6 & 61 \\
F & $790-800$ & 143 & 1 & 1 & $92+5$ & 8 & 75 \\
G & $800-820$ & 29 & 0 & 1 & $8+6^{\text {a }}$ & 2 & 59 \\
H and I & $820-850$ & 73 & 18 & 3 & 22 & 1 & 60 \\
B-I & $705-850$ & 351 & 23 & 5 & 176 & 19 & 64 \\
\hline
\end{tabular}

Following the procedure in Feveile and Jensen (2006), stones that cannot be related more precisely than to two subsequent phases are placed in the youngest phase (e.g. stones in D/E are placed in E). The numbers of such finds are italicised

Two whetstones from ASR 9, one possibly from Eidsborg and one from Mostadmarka, are related to the phases I-J, and thus placed in phase $\mathrm{J}$ dated to the twelfth to thirteenth centuries, and consequently not included in this study

${ }^{a}$ Four of these six stones are from three subsequent phases, E/F/G, and are here related to the youngest of them, G. In the publication from Feveile and Jensen, however, such finds were placed under the group "without phase" (Feveile and Jensen 2006). Consequently, the total number of whetstones from phase G is also increased by four in relation to Feveile and Jensen 2006, Fig. 9.13

${ }^{\mathrm{b}}$ The phases $\mathrm{H}$ and $\mathrm{I}$ have the same dating frame, 820-850, and are thus merged here. Seven of the finds from Mostadmarka were related to the phases $\mathrm{G}-\mathrm{H}$, whereas the rest were related to the phases $\mathrm{H}-\mathrm{I}$

whetstones from reliable contexts are included in the analysis, comprising 351 fragments from the phases B, C, D, E, F, G, H, and I (See Table 6). ${ }^{7}$

$64 \%$ of the total number of whetstones from ASR 9 is assumed to originate in Eidsborg or Mostadmarka. Numbers of stones are too low in the pre-725 phase (B) to provide percentages of significance, but possible Mostadmarka whetstones occur there. In the 725-60 phase (C) whetstones from Eidsborg and Mostadmarka constitute nearly more than $40 \%$ of

\footnotetext{
7 Two stones from ASR 9 that were included in the geological analyses (ASR $9 \times 363$ and ASR 9x311) are not securely dated to the Viking Age, and thus not included in the chronological analysis.
} 
Table 7 Assumed origin of the six investigated whetstones from ASR 4M75, ASR 5M74 and ASR 13

\begin{tabular}{lllll}
\hline Date AD & Eidsborg & $\begin{array}{l}\text { Possible } \\
\text { eidsborg }\end{array}$ & Mostadmarka & $\begin{array}{l}\text { Possible } \\
\text { mostad- } \\
\text { marka }\end{array}$ \\
\hline $720-800$ & 0 & 0 & 4 & 0 \\
c. $1000-1200$ & 2 & 0 & 0 & 0 \\
\hline
\end{tabular}

the total, thereafter increasing gradually to $75 \%$ in the $790-800$ phase (F). In the first half of the ninth century $(\mathrm{G}, \mathrm{H}-\mathrm{I})$ they constitute more than half of the total.

All four fragments studied from ASR 4M75 and ASR 5M74 dated to 720-800 originate in Mostadmarka, whereas the two fragments from ASR 13 originate in Eidsborg (Table 7).

Summing up, $47 \%$ of the whetstones from ASR 7 and 64\% from ASR 9-60\% of all whetstones from the two sites - are assigned to two quarry sites in the western part of the Scandinavian Peninsula. ${ }^{8}$ Whetstones of purple very fine-grained schist considered to originate from western Scandinavia are previously identified in phase C (725-760) by Feveile and Jensen, but without any provenance to specific quarry sites (Feveile and Jensen 2006:140). Thus, this study identifies for the first time the origin of the very fine-grained schist—both purple and dark grey_-documenting long-distance trade in commodities from Arctic Scandinavia to Ribe in the eighth to mid-ninth centuries. The material suggests that since the second quarter of the eighth century, possibly before, people in Ribe received a substantial proportion-since c. 760 a majority-of their whetstones from northern supply networks. The occurrence of these stones in Ribe's earliest phase (B) coincides with the earliest occurrence of finished reindeer combs there, and the peak in the proportion of west-Scandinavian whetstones in phase F (790-800) overlaps with the earliest occurrence of reindeer antler raw material (phase E-F, 780-800) (Ashby et al. 2015).

Possible and securely provenanced whetstones from Mostadmarka $(\mathrm{N}=233)$ outnumber Eidsborg stones $(\mathrm{N}=38)$ by approx. 6:1; except for phases $\mathrm{H}-\mathrm{I}$ the latter occur only sporadically. In phase $\mathrm{H}-\mathrm{I}(820-50)$ stones from Eidsborg and Mostadmarka are nearly equally numerous.

Of the total whetstone material from the excavations in Kaupang 2000-2002 (c. 800-960/80), whetstones of the Mostadmarka type constitute approx. 60\% ( $\mathrm{N}=1017)$ and stones of Eidsborg type approx. 15\% ( $\mathrm{N}=257)$; the remaining 25\% $(\mathrm{N}=424)$ represent other rock types. Eidsborg-type stones appear to increase with time; in the earliest phase (c. 800-805/810) there are none, while 8 of the Mostadmarka type were retrieved. In phase SP II (805/10-840/50) Mostadmarka-type stones $(\mathrm{N}=81)$ outnumber those of the Eidsborg type $(\mathrm{N}=12)$ by approx. 7:1. From the disturbed phase SP III, which contains finds from c. 830-980, the relation between the two types is approx. 3.8:1 $(\mathrm{N}=928$ and 245 respectively) (Resi 2011, Figs. 14.2, 14.6, 14.15).

Thus, from the early 800s onwards, a gradual shift towards a higher proportion of Eidsborg-type whetstones can be observed in both Kaupang and Ribe. ${ }^{9}$ Despite Kaupang's proximity to Eidsborg-about $130 \mathrm{~km}$ as the crow flies-Mostadmarka-type whetstones

\footnotetext{
8 These figures accord well with Myrvoll's (1991) and Hald's (1991) identification of a total of 65.5\% Eidsborg and 'metasiltstones' among the 117 whetstones from the Ribe excavations 1970-6.

9 This tendency continued after the turn of the millennium. In eleventh to fourteenth century Oslo, Eidsborg-type whetstones outnumber the very fine-grained schist by 12:1 (Oslogt. 6 site, $\mathrm{N}=28: 350$; Lønaas 2001:15-16; Skre 2018c:10).
} 
there constitute a larger proportion compared to Eidsborg-type stones (approx. 6.8:1) than they do in Ribe (approx. 2:1) for the period when the two sites existed in parallel (c. 800-850). The sailing distance from Mostadmarka is about the same to Ribe as to Kaupang-approx. $1100 \mathrm{~km}$. Possibly, the increase in Eidsborg whetstones in Ribe c. 820-850 (phase $\mathrm{H}-\mathrm{I}$ ) may be connected to the establishment of Kaupang and increased traffic between the two sites across Skagerrak, a sailing distance of some $460 \mathrm{~km}$. The contemporary limited but abrupt increase in soapstone items in Ribe (above, n. 4) supports this suggestion. Until the predominance by Eidsborg whetstones in the eleventh century, Mostadmarka stones constituted the majority of whetstones in Ribe, Kaupang, and Hedeby. ${ }^{10}$

\section{Discussion}

It appears that since the early eighth century and well into the twelfth, there was a steady supply of whetstones from Mostadmarka to markets and urban sites in southern Scandinavia. The precise volume is hard to determine, but a rough estimate suggests that in Ribe an annual average of approx. 170-200 fragments of Mostadmarka and Eidsborg whetstones were deposited. ${ }^{11}$ In some cases, multiple fragments may have come from the same whetstone; however, many of those who acquired whetstones in Ribe, particularly during the site's seasonal-marketplace phase, will have used them elsewhere and discarded the remains there. Hence, as an absolute minimum, an average annual supply to Ribe of several hundred Mostadmarka and Eidsborg whetstones-until c. 820 nearly all of them from Mostadmarka - seems likely, sufficient to cover more than half of the demand among craftsmen, traders, and other buyers there.

The likely shipping site for the Mostadmarka whetstones is Lade, 20-25 km north-west of the two Mostadmarka quarries (Figs. 1 and 3). From the late ninth to the early eleventh centuries the prominent manor Lade (Old Norse Hlaðir, 'storing place' or 'loading place') was the residence of five generations of Lade Earls, high-level political agents in Scandinavia. The first of these, who apparently already resided at Lade (Schreiner 1928:9-10), became King Harald Fairhair's earl, while the last ruled Norway as the earl of the Danish kings Harald Bluetooth and Sven Forkbeard. The manor is situated in the second richest agricultural region on the western coast (after Jæren in Rogaland, Fig. 2), on a small promontory with several natural harbours on the southern shore near the mouth of the Trondheim Fjord.

According to the skaldic poem Háleygjatal ('Enumeration of the Háleygir', composed c. 985), the Lade Earls originated in Hålogaland, which comprises the approx. $650 \mathrm{~km}$ of coastland from northern Trøndelag to the Malangen/Lyngen area (Fig. 2). Further north and east lay Finnmark, the land of the Finnas (Sámi). From these northern regions came highly desirable goods that the Háleygir obtained from the Finnas. Describing his commodities during his visit to King Alfred's court c. 890, Ohthere from Hålogaland listed walrus tusk (ivory), rope from walrus and seal hide, down and feathers, and fur from marten, bear, otter, and reindeer (Bately 2007:46).

\footnotetext{
${ }^{10}$ Reliable classifications of whetstones have been published from the following sites: In ninth to eleventh century Hedeby, the Mostadmarka whetstones outnumber Eidsborg by 3:1 ( $N=7374: 2419$; Resi 1990:17). In twelfth century Bergen the ratio is 1:3 $(\mathrm{N}=23: 74$; Hansen 2017), and in eleventh to fourteenth century Oslo it is 1:12 (see note 9).

${ }^{11}$ The estimate is produced using the procedure developed by Jensen and Feveile (1993).
} 
This trade had a long history prior to Ohthere's time. Jordanes, in his mid-sixth-century History of the Goths (ch. 19, Mierow 1915:56), writes of the Adogit (alogii) people in Scandinavia, who live where summer has 40 days without nights and the winter 40 days without sun. The description fits Hålogaland, and the Adogit are commonly identified as Háleygir (Sitzmann and Grünzweig 2008:21-22; Svennung 1967:32-41). Jordanes also mentions the neighbouring Scrithifinni, apparently the Finnas, which he identifies as hunters and gatherers. From these northern regions come exquisite furs enjoyed by the Romans, Jordanes reports (ch. 21, Mierow 1915:56).

Evidence collected in Hålogaland demonstrates increasingly larger and more seaworthy ships and a rise in seafaring from the seventh century onwards (Storli 2006:22), in tandem with an aristocratic stratum with access to long-distance goods. A number of prominent manors have been identified along the coast (Fig. 8; Berglund 1995; Hansen and Olsen 2004; Holberg 2015), but only one of these, in Borg, Lofoten, has been thoroughly excavated: In the remains of the hall section of a 67-meter longhouse, rebuilt to 83 meters, shards from 15-16 glass vessels were found as well as 36 glass beads, rather evenly spread out over the longhouse's existence (seventh to tenth centuries). Six vessels can be provenanced respectively as Anglo-Saxon (one from the seventh century, two from the eighth), Rhinish (one, eighth century), and Continental (two, ninth to tenth centuries). The beads are less securely provenanced; they were probably imported to Scandinavia and are common occurrences in southern Scandinavia and the Baltic (Holand 2003; Näsman 2003).

Although the Borg finds demonstrate that glass vessels were available to seventh to tenth century west-Scandinavian aristocrats, the latter, unlike their peers in southern and southeastern Scandinavia, did not include them in grave furnishings (Holand 2001:164-165). Fortunate depositional and post-depositional circumstances and the sieving strategy applied in the particularly find-rich north-western corner of the hall section appear to be the main reason for the uniqueness of the artefact assemblage in Borg. ${ }^{12}$ However, the frequent occurrence of glass beads and copper-alloy brooches in graves in Hålogaland (Eldorhagen 2001; Vinsrygg 1979 tables II-IV) and elsewhere in western Scandinavia (Røstad 2016:52-92, 273-97) corroborates the eighth-century phenomenon evidenced by the Ribe whetstones: Regular long-distance trade from the Arctic to the southern North Sea zone was indeed undertaken from aristocratic manors, including other than Borg, in the seventh-eighth centuries.

In written evidence, the trade in commodities acquired from the Finnas through tax, tribute, trade, and plunder is a recurring theme in royal politics from the time of the first king of Norway, Harald Fairhair (reign c. 872-932), until the twelfth century. Harald secured the transport of these and other commodities along the coastal sailing route, the Norðvegr (Fig. 2), by naming local chieftains earls of the main regions along the route; its southern end in Hordaland and Rogaland was his own heartland (Skre 2018b). In Møre he appointed Rognvald and in Trøndelag/Hålogaland appointed Håkon, the first Lade Earl (Fig. 2).

Prior to that, a prime driver behind political integration processes along the route seems to have been the securing of seaward traffic in general, but in particular probably the transport of Arctic commodities to sites and markets along the west-Scandinavian coast and in the southern North Sea zone. Integration of Hålogaland and Trøndelag appears to have developed well before Harald's time (Bratrein and Niemi 1994; Holberg 2015; Koht

\footnotetext{
12 Frands Herschend has kindly supplied detailed information on the Borg sieving regime (email 2018.02.20).
} 
Fig. 8 Datable Insular loot deposited in Scandinavia (based on Wamers 1985). The three sea-king zones along the west-Scandinavian coast are indicated (based on Hansen and Olsen 2004:59; Skre 2018b:790). Illustration: Ingvild T. Bøckman

1919:16; Schreiner 1928:9-10). Lade, positioned at the southern end of this long stretch of land, is a likely place where a variety of Arctic commodities from Finnmark, Hålogaland, and Trøndelag were stored-the latter region would contribute whetstones and possibly iron (Stenvik 1997) and furs (Holm 2015; Lindholm and Ljungkvist 2016) from the neighbouring woodlands - to be loaded onto ships headed for southern markets. The common occurrence since the late-sixth century in several east-Scandinavian regions of gaming pieces made from North-Atlantic whalebone (Hennius et al. 2018) suggests that the Hålogaland/Trøndelag trade network also extended overland eastward to the Baltic.

The steady supply of Mostadmarka whetstones to southern Scandinavia through the eighth to eleventh centuries and the quarry's proximity to Lade suggests that these stones were a common commodity in the ship-bulk of long-distance traders from Trøndelag and Hålogaland. All the commodities mentioned by Ohthere were high-value items for a narrow group of buyers: either luxuries (down, ivory, fur) or sought-after utilities (ship-ropes from hide). These high-quality products from Arctic Scandinavia were in high demand in the aristocratic segment in the Continent and the British Isles. At the same time, Ohthere's list should not be taken as exhaustive; the commodities recorded would have been of interest to his audience of royal scribes and officials, whereas commodities for craftsmen and the general population, such as reindeer antler (Ashby et al. 2015), oil from marine mammal blubber (Nilsen 2016), gaming pieces from whale bone (Hennius et al. 2018), and whetstones, might not have been deemed worthy of mentioning in the royal quarters.

All materials in Ohthere's list are perishable and are only preserved in exceptional cases. ${ }^{13}$ The identification of the Mostadmarka origin of a substantial portion of whetstones in sites such as Ribe, Hedeby, Kaupang, and Oslo adds a non-perishable commodity to the list. Their continuous occurrence in high volumes at these sites allows their cautious use as a proxy for the trade in commodities from the Arctic transported on the Norðvegr along the western coast of the Scandinavian Peninsula in the seventh to tenth centuries.

\section{Taking Up Raiding in The West (c. 789-850)}

Essential constraints and opportunities of Viking-ship commanders of the 780s-850s are discussed in the following, suggesting how they may have influenced their decisions on where to raid in various periods. The discussion is framed by the substantial trade in Arctic commodities along the west-Scandinavian coast evidenced by the Ribe whetstones. The interests of various groups in this trade produced both conflicts and coalitions.

The most prominent concern of Viking-ship commanders is the coalition between one of their primary targets, long-distance traders on the Norðvegr, and kings along the route. While this coalition appears to have had existed since the Roman Period, strengthening of royal authority in the late eighth century posed an obstacle for Viking-ship commanders, who now faced a stronger adversary.

Their second concern, emerging through the 820s-30s, was that they were victim to their own success: the profitability of overseas raiding attracted increasingly greater

\footnotetext{
13 Some Continental and British walrus-ivory items from c. 300-870, before hunting began in Iceland and Greenland, are mentioned by Roesdahl (1995:13-14, 2005:184).
} 


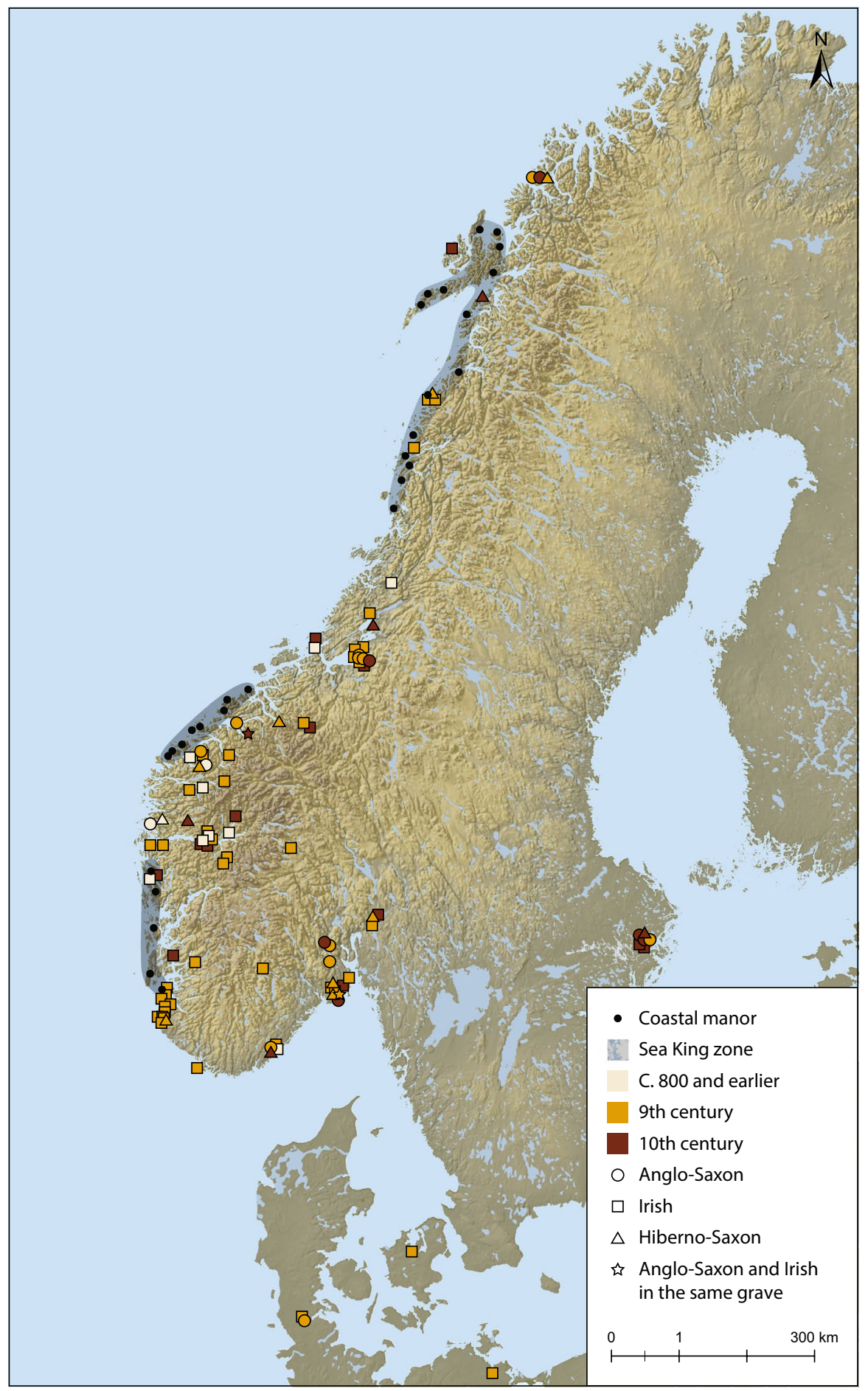


numbers of ships and men to that enterprise, with the resulting competition reducing their spoils. However, this situation also produced a new opportunity: raiders could join forces in Viking fleets that had the necessary strength to conduct successful raids on prosperous and well-defended sites. By overwintering overseas, Vikings could reduce the danger of retaliation from kings and traders based in the homelands for raiding lands and waters where the latter wanted to maintain peace.

Thus, we suggest that Viking raiding overseas began as Vikings became the weaker party in a longstanding conflict in the homelands. That such 'push' factors were the key trigger is supported by the character of the earliest raiding. During the first 15-20 years of overseas raiding Vikings struck at widely dispersed sites (see below), suggesting that they were not 'pulled' to certain lands so much as they were 'pushed' into searching for prey in new waters. As their activities gained volume and momentum through the $820 \mathrm{~s}-30 \mathrm{~s}$, the homeland conflict with traders and kings maintained significant influence on where Vikings raided. However, 'pull' factors (e.g. the weakening of the Frankish Emperor's power in the 830s) attained more significance as Vikings overseas gained numbers and strength.

\section{Traders, Kings, and Vikings (Seventh-Ninth Centuries)}

Regarding his northward voyage to the Beormas, Ohthere reports that he did not enter their land for unfriðe, often translated as 'because of hostility' (e.g. Bately 2007:45, 56-7). However, Christine Fell (1982-3) convincingly argues that the term has a more specific meaning, namely that Ohthere did not have the personal frið status among the Beormas that would have allowed him to travel safely into their land.

There is no mention of such hindrances on Ohthere's southwards journey along the Norðvegr and into Skagerrak and Kattegat to Hedeby, or indeed across the southern North Sea to King Alfred's court in Wessex. The latter is a case in point for Fell's conclusion (1982-3:96) that frið was a personally held privilege and not necessarily affected by hostilities between people from the very same polities or regions. King Alfred's realm had suffered substantial Viking incursions throughout his lifetime. Apparently, the King still granted frið to this man from Arctic Scandinavia, presumably because he identified himself and was accepted as a trader. Ohthere must have received the same privilege by others to be permitted to travel across the various political and cultural zones on his long route.

Thousands of windblown and mostly barren islands and skerries protected Ohthere's voyage along the west-Scandinavian coast from the rough winds and waves in the Atlantic Ocean. But intermittently along the Norðvegr occur pockets of relatively fertile land. In the best of these were situated manors rich in monuments and lavishly furnished graves spanning the early Bronze Age to the Viking Age. While rich finds also occur in the much more fertile and densely settled districts in valleys and along fjords further inland, the archaeological record of the outer-coast manors is unsurpassed. Among them, in Rogaland and Hordaland, are the five manors that according to the Icelandic saga tradition belonged to Harald Fairhair. Further north are two additional coastal-manor zones, one in Møre and the other in Hålogaland (Fig. 8). Between the three zones the islands and headlands along the sailing route are too barren to support large or numerous settlements.

Avaldsnes, the most prominent of these coastal manors, is situated at a bottleneck on the sailing route's southern end (Figs. 1 and 2). Based on excavations here, Skre (2018b) argues that from the third to the eleventh centuries these manors served as supply bases for the sea kings who exerted authority over the sailing route. By fighting Vikings who 
lurked in the innumerable islands and bays along the route, the sea kings could provide safe sailing for traders and other travellers. Snorri recounts in Harald's Saga (ch. 22) that every summer Harald and his army searched the islands and outlying skerries, pursued the Vikings that camped there, and drove them over the sea to the west - all the way to the Irish Sea. In the same saga (ch. 24) Snorri writes that Harald outlawed Rolf, the son of his close ally Rognvald, because he had harried in Viken (Fig. 2); the king had strictly forbidden robbery in the realm. Of course, there is ample reason for scepticism about the historicity of Snorri's accounts, committed to parchment some 300 years after the events. Nevertheless, outlawry is precisely the penalty stipulated in the west-Norwegian Gulaping law code (ch. 314) for those who renounce the frið and ravage the homelands. Scourging one's home district was even worse; it was considered an honourless deed and perpetrators were declared níðingr, irredeemable outlaws.

Frið arrangements with kings and earls who controlled various stretches of the Norðvegr, surely involving payment of shares to the latter, would have been vital for longdistance traders as well as for other travellers. Although aristocrats would have had their own ships and men to defend their lives and cargo, it would have lain entirely within their interest to support royal peacekeepers along the route. While the power balance between Vikings on the one hand and traders and kings on the other varied through the centuries, the constellations and roles would have remained relatively constant during the periods when manors along the route show evidence of sea-kings' presence. At Avaldsnes such evidence (i.e. monuments, remains of halls and other prominent buildings, and extensive food processing) is found from the mid-third to the eleventh centuries (Skre 2018a).

The same person could of course be a trader, Viking, and royal warrior in different waters or at different times - after all, the same skills were needed by all three: seamanship, negotiating abilities, and martial proficiency. While some sea kings mentioned in sagas and skaldic verse were evidently Vikings, Harald appears to have been a warrior who rose to power in a peacekeeping sea-king milieu along the sailing route in Rogaland and Hordaland, subsequently extending his realm from the sea route to the inland (Skre 2018b). Other rulers (e.g. Olav Tryggvason, reign 955-1000) appear to have spent time in service to kings in other lands and participated in Viking raids before they became kings in their own right.

From the late ninth century, Harald Fairhair and his earls controlled practically the entirety of the Norðvegr sailing route. Already by the late eighth century, kingship appears to have developed at the southern end of the route, in Rogaland and southern Hordaland. Based on new datings from three assembly sites in Rogaland-so-called courtyard sitesIversen (2018) provides empirical support for Myhre's (1992) suggestion that in the eighth century trans-regional royal power emerged there. Independently of Iversen and based on other types of evidence, Stylegar and Bonde (2016) date this rise of kingship by the southern end of the Norðvegr to the late eighth century. They maintain that kingship there was modelled after the Anglo-Saxon version, and that the burial rites of the two first Scandinavian ship graves near Avaldsnes-the ships were built c. 770 and 780 and entombed in 779 and the early 790s respectively-were modelled on the Sutton Hoo ship burial in East Anglia (Stylegar and Bonde 2016:10-13).

The increase in the 780s and peak in the 790s in the total number of whetstones deposited in Ribe each year-annual average in ASR 9 of 3.3 and $14.3(\mathrm{~N}=33$ and $\mathrm{N}=143$ respectively, see Table 6) in the two decades respectively-reflects increased activity there. The reason for the increase is probably that this period saw the heyday of trade in the Channel and the southern North Sea zone (Coupland 2002; Verhulst 2002:92). However, the percentage of Mostadmarka whetstones also rises in these two decades to a peak of 
75\% (ASR 9), probably reflecting a vast increase in trade in Arctic commodities, both in relative and absolute volume. Likely, the main reason for this is the existence of a polity in Rogaland and southern Hordaland that was sufficiently strong to guarantee safe sailing in adjacent waters, and thus, with whom Arctic traders could make frið arrangements. Contemporary developments of royal authority over Viken (Fig. 2) and southern Scandinavia under Sigfred and his son Godfred, kings of the Danes, may be the reason why Frisian and Slavic traders sought the town Kaupang from its very founding c. 800 (Skre 2011a).

\section{The beginning of Viking Raiding Overseas}

It appears that the earliest Viking raiders in the west emerged from the western coast of the Scandinavian Peninsula, suggesting a connection to the contemporary peak in the transport of Arctic commodities along the very same coast and the building up of royal authority there. Following a brief summary of the whens and wheres of the early raiding, these suggested connections are explored below.

Beginning in 789, the earliest reported Viking raids in the west were a series of disparate attacks on coastal settlements from the Bay of Biscay in the south to the Atlantic Scottish Isles in the north (Fig. 1). While, surely, many attacks are unreported, the overall chronology in England, Francia, and Ireland is rather well testified. Northern Scotland is the least reported (Barrett 2008), but was probably targeted early. Based on reported raids, beginning in Portland in Dorset in 789, the English Channel coast from Kent and westwards seems to have been hit first (Downham 2017). Thereafter, raids are reported in Lindisfarne in 793 and Monkwearmouth (both in Northumbria) in 794, Ireland and Scotland in 795 (Ó Corráin 1998), Isle of Man in 798, and Aquitaine and the southern Channel coast in 799 and 800 (Walther 2004:168-170).

From c. 806 raiding centred on Scotland and Ireland, and for the following 30 years nearly all raids were conducted there, escalating sharply through the 820 s and 30s (Etchingham 1996:Fig. 2). ${ }^{14}$ Ó Corráin (1998:27-28) suggests that from 814-20 (the only period after 806 when chroniclers do not report attacks), Vikings were busy in Scotland, while Colmán Etchingham (1996), based on more recent evidence, has disputed the notion that the lack of chroniclers' reports necessarily reflects a hiatus in raiding in Ireland for those years. From the mid-830s, Viking activities entered a third phase: larger armies attacked Ireland, England, and Francia, penetrated inland, and in some cases began overwintering.

There is little Insular or Continental evidence as to where in Scandinavia the ship crews of the pre-mid-830s raids originated; the information in the Anglo-Saxon Chronicle that the ships in Portland 789 came from Hordaland is an addition to the chronicle a century after the event (Downham 2017) and thus less reliable. The origin of the culprits in the early raiding in northern Great Britain and Ireland, however, is indicated by Scandinavian evidence. Except for a single piece in eastern Agder, the buried Insular loot from around 800 or slightly earlier has been retrieved solely in the five neighbouring regions of northern Hordaland, Sogn, Nordfjord, Møre, and Trøndelag (Fig. 8; Wamers 1985:49-56). Admittedly, such items may already have been old when taken, and burial customs in southern Scandinavia provide a meagre basis for quantitative comparison with those of the western

\footnotetext{
14 The Danish King Godfred's raids in Saxony 804 and in Frisia 810, and his sons' raid in 815, were not Viking raids but moves in royal territorial disputes. The attack in 820 on several sites in the Empire by a fleet of 13 piraticae naves from Nordmannia, however, was clearly a Viking raid, the only one recorded in the Empire between 800 and 834 (Nelson 1997:22-23; Walther 2004:171).
} 
Scandinavian Peninsula. Still, the distinct concentration of the earliest loot within a rather narrow area instils confidence in the conclusion that most raiding into Scottish and Irish waters in the pre-806 phase, possibly also somewhat later, emanated from these few regions on the west-Scandinavian coast (Ó Corráin 1998:1-2; Wamers 1985:85; Williams 2008:193). From Heen-Pettersen's (2014) analysis of the Trøndelag finds it appears that the earliest raids were organised from prominent and well-established aristocratic manors.

No such find patterns can guide the search for the origin of the early raiders in England and Francia, but western and southern Scandinavia is a safe bet. The royal power that emerged in southern and western Scandinavia in the late eighth century will have had two effects, both of which produced redundant military capacity. Firstly, royal power would have subdued rivalry between smaller polities and among royal pretenders, and leaders previously engaged in such unrest will have been ready to direct their troops elsewhere. Secondly, royal power provided safe sailing for traders, thus reducing spoils and increasing risks for Vikings who previously had parasitized on traders. Some of this excess military capacity may have joined a king's retinue or taken up long-distance trade. However, the latter enterprise was available only for those who produced or had access to commodities that were in demand overseas. For those who lacked access to such goods or were not involved in the protection of the sailing route, there were few alternatives to taking up plunder in new waters if they hoped to partake of the benefits enjoyed by their peers among traders and in the king's service.

Once rising royal power put the damper on raiding close to home, warriors and ship commanders in southern and western Scandinavia would have looked overseas for alternative hunting grounds. Through several generations' recurring trade ventures in the southern North Sea zone, Scandinavians would have collected knowledge from traders and sailors of lands and waters in all the areas affected by the earliest raids-details would have been extracted from captives taken en route.

Why, then, was raiding c. 806-35 concentrated in Ireland and Scotland? Hypothetically, resistance was weaker there. Elsewhere, Vikings may have been put off by defensive measures, for instance by Offa's upholding in 792 of the obligation of churches and monasteries in Kent to contribute to the defence 'against seaborne pagans with migrating fleets' (Downham 2017:5), by the alleged slaughter of 105 of the Paganae vero naves that attacked Aquitaine in 799, and by Charlemagne's building of a fleet and establishment of watch posts in 800 to defend against pirates that troubled the sea outside Gaul (Walther 2004:168-169). However, on several occasions in Ireland, efficient and successful resistance was indeed mustered (Ó Corráin 1998); a more complex background for the concentration of Viking activities to Ireland and Scotland must be sought.

Another contributing factor to the three decades' confinement of Viking raiding to Ireland and Scotland is that raiding there did not interfere with the prosperous trade in the southern North Sea zone and the English Channel. Royal peacekeepers and traders along the Norðvegr and in southern Scandinavia would have had an interest in preventing raids in the lands and waters where they traded; that Vikings in this period returned to the homelands each year kept them within reach of royal power and aristocratic traders.

In an abrupt shift in the mid-830s, extensive Viking raiding commenced in England and in the Empire. Unprecedented in magnitude, this wave of raiding has been considered to have dealt a blow to craft production and trade in those countries. Dorestad was sacked in 834 and annually again for three consecutive years. The internal disputes between Louis the Pious and his rebellious sons in the early 830s and among his sons following his death 840 left the Empire vulnerable. For several decades, coasts and riverbanks from Frisia to Bordeaux were heavily and repeatedly sacked (Nelson 1997; 
Walther 2004:171-177). In England a large army landed in 835 on Isle of Sheppey in the Thames Estuary, heralding several decades of intense raiding in England, targeting towns (Southampton in 840 and 842, London in 851), culminating in the invasion in 865 of the Great Heathen Army that ravaged eastern and northern England for more than a decade.

How did the interests of Vikings come to eclipse those of Scandinavian traders in the mid-830s? This is a complex issue and we will restrict the discussion to suggesting some factors that may have contributed to these developments. As a prelude, the question of precisely how harmful Viking raids were to trade needs to be weighed. Hodges (2006:157-162) has downplayed the significance of raids, arguing that in the 830s, trade in the southern North Sea zone was already dwindling, while Dorestad, London, and Southampton were in recession; thus, Viking attacks were not the main reason for the slump in trade and the abandonment of towns around 850. However, the archaeological evidence he refers to is not dated with sufficient precision to determine whether the recession began before, during, or after the 830s. The trade in Arctic commodities in Ribe appears to have remained on a consistently high level even in the town's final phase in 820-50; there is no indication of Hodges' suggested pre-830s recession. When production and trade in Ribe dwindled, this was probably due to the breaking of trade connections to the south and west, particularly to Dorestad. Clearly, Hodges is right that the recession in Carolingian economy in the mid-800s has a complex background, but his reasons for minimizing the impact of Viking attacks on this development do not seem convincing.

Trade in the Baltic prospered in these years as the eastern riverine routes towards the Finns, Slavs, Kahzars, Bulgars, Arabs, and others opened, and urban sites in the Baltic flourished (Callmer 2007). Kaupang's trade links to the southern North Sea zone were broken off c. 850, probably because trade in Ribe and Dorestad tailed off. Contemporaneously, brooch types from the west-Scandinavian coast, which did not occur at Kaupang in the early ninth century, began to predominate in cemeteries there. Evidently, trade routes along the western coast of the Scandinavian Peninsula shifted from the North Sea zone to Skagerrak, Kattegat (Skre 2011b), and the Baltic (Skre 2018c:15) — the very route followed by Ohthere.

In view of the above, it seems likely that the Viking raids in England and the Empire from the mid-830s were detrimental to trade in the southern North Sea zone, and were thus contrary to the interests of kings and traders in western and southern Scandinavia. Why, then, were they not stopped?

Firstly, the Danish King Horik's message to the Emperor that he had captured and killed those who had raided Frisia in 836 (Nelson 1997:24) indicates that royal attempts to quell overseas raiding were in fact being undertaken. The battle against returning Vikings that led to Horik's death in 854 may have resulted from such controversies. Secondly, the motivation on the part of Scandinavian kings and traders to stop Viking raids in the North Sea may have been undercut by the viable alternative in the Baltic trade. Thirdly, and possibly most importantly, Vikings gained much greater independence from kings and traders when they began overwintering overseas in the mid-830s; they were less dependent on frið in the homelands and were out of reach for kings and traders based there, hence more difficult to subdue.

In parallel, there is potentially a 'pull' factor behind overwintering overseas. While the first fleets that ravaged Ireland were small, the two fleets that entered the Liffy and the Boyne in 837 were each composed of 60 ships and carried a total of some 3000 men (Ó Corráin 2008:429). Kurrild-Klitgaard and Svensen (2003) hold that because successful raiding attracts other pirates over time, the success of roving raiders produces a 'common pool resource problem', reducing the share of spoils for all raiders. When proceeds decrease below an acceptable level, one solution would be 
to establish a settlement in the vicinity of the potential loot so as to exclude others from raiding in the surrounding territory. While Kurrild-Klitgaard and Svensen see this as the logic behind state formation and taxation, it may equally well contribute to explaining the two shifts in Viking behaviour in the mid-830s: the start of overwintering and the taking up of raiding in England and the Empire. The motif of establishing well-defended longphuirt in Ireland (Sheehan 2008) may not have been to protect only against the Irish but also against other Vikings who sought to obtain spoils from the region. Thus, defended Viking bases in Ireland and Scotland may have compelled latecoming Viking-ship commanders to look elsewhere for prey. As the numbers of Vikings increased, attacks on prosperous towns and regions in southern England and Francia became realistic ventures. Large fleets that could undertake such operations were formed through agreements between ship commanders, possibly up to 50, each in command of only a few ships (Price 2016:164). Drawing on parallels to seventeenth to eighteenth century piracy, Price $(2014 ; 2016)$ uses the term hydrarchy to characterise this distinctive Viking strategy of joining and splitting up forces depending on the target's strength. It ensured that satisfactory proceeds for all raiders could be obtained from a large force's attack on a well-defended town as well as from a small unit's pillaging of a less rich and less protected monastery or settlement.

The earliest record of overwintering refers to Ireland in 836, the first in the Empire at Noirmoutier Island off Aquitaine in 843, and in England on Thanet Island in Kent in 850. However, all these instances may have been preceded by overwintering in Scotland. Permanent Viking camps in Scotland, possibly also in Ireland, appear to have been the bases from which many of the subsequent raids set out for England and the Empire, not to mention for occasional raids against the west-Scandinavian coast. The paucity on the western coast of the Scandinavia Peninsula of Frankish and south-Anglo-Saxon buried loot as compared to Northumbrian, Scottish, and Irish loot suggests that few of those who pillaged in the south returned to the western coast of the Scandinavian Peninsula, and conversely that some of those who pillaged in the north did return to the homelands.

Irish annals mention no kings among the Vikings until 848, after which their deeds were mentioned on several occasions. Their main mission, it seems, was not primarily to raid the Irish, but to assert control over the Vikings who were already based there (Ó Corráin 1998). There has been a lengthy debate as to where these kings ruledtheir land is called Laithlinn-in Scotland (Ó Corráin 1998) or in what later became Norway (Etchingham 2014). That question is connected to the debate on the origin and nature of two groups of foreigners identified in the annals in these years, the Finngall ('fair') and the Dubgall ('dark'); the latter arrived to attack former (Downham 2011). While this discussion involves intricate philological and historical problems that will not be addressed here, we suggest that the conflicting interests of overwintering Vikings on the one hand and west-Scandinavian traders and royal peacekeepers on the other may be of relevance for these debates.

\section{Concluding Comment}

As discussed in the beginning of this paper, the primary driver for economic complexity within regions in early medieval Europe appears to be aristocratic wealth. Moreover, that complexity, including commodity production, is a prerequisite for long-distance trade and the establishment of urban markets. 
However, this model, advocated primarily by Wickham (2008), does not quite suit the early medieval west-Scandinavian case. At least at times in this long period, agents in the aristocratic segment, identifiable along the whole coast since the Roman Period, were engaged extensively in long-distance trade and represented a substantial demand both regionally and during trade expeditions. Additionally, political integration along the coast beginning in the seventh century, if not before, led to the economic integration of substantial regions with diverse resources, providing ample opportunities for developing intraregional economic complexity and wealth.

While the whetstones form Mostadmarka that form the empirical basis of this paper were produced close to the aristocratic manor Lade, it seems that most other commodities that the Håløygi and the Trønder brought into long-distance trade were not produced within their region but were acquired from neighbouring peoples such as the Finnas and the Beormas. Ohthere's report is explicit that his wealth consisted of what he acquired from the Finnas, rather than from his own land. While economies may have been more complex further south along the coast, as in Møre, Sogn, Hordaland and Rogaland, military leaders in these regions appear to have had two conflicting sources of profit: protecting and parasitizing on long-distance traders from the Arctic.

Thus, the wealth of the west-Scandinavian aristocracy to a lesser degree derived from intraregional economic complexity; hence the late establishment of markets and urban sites. Exchange of commodities for long-distance trade was not dependent on market sites alone: the Finnas' payments of tax or tribute was bound by personal connections and obligations. Commodities thus acquired, as well as whetstones and other goods produced at or near aristocratic manors, were loaded onto ships that brought them to markets and towns in southern Scandinavia and in the southern North Sea zone, where traders could acquire attractive commodities in exchange. The western coast of the Scandinavian Peninsula appears to be one of what Wickham (2008:22) calls 'a tiny handful of regions whose economic complexity was determined by their commitment to external exchange'.

Variations in intraregional economic complexity, aristocratic wealth, and long-distance trade will be found all over Scandinavia. Similar types of agents as in the west-traders, kings, and Vikings - will also be found elsewhere, but their relative and absolute strength and constellations will vary from region to region; so too will factors like the size of regions and the socioeconomic significance of landed property, of commodity production, and of long-distance trade. The Viking phenomenon is varied and complex and the onset of Viking raiding cannot be captured within a single explanatory framework no matter how extensive and detailed. Still, the current steady flow of new evidence regarding the provenance of materials and the movements of people will undoubtedly continue to remodel, extend and refine the understanding of this transformative period in Northern Europe.

Acknowledgements We are greatly indebted to Head Curator Morten Søvs $\varnothing$ and Curator Mette Søvs $\emptyset$ at Museet Ribes Vikinger, who generously gave access to the Ribe whetstones, permitted analyses, and, together with Curator Claus Feveile, provided information on finds contexts. Steven Ashby, Matthew C. Delvaux, and Professor Frands Herschend have supplied useful information. Professor Søren M. Sindbæk (Århus University), Associate Professor Zanette Glørstad (University of Oslo), and Researcher Tor Grenne (Geological Survey of Norway) have contributed inspiring and productive comments to an earlier version of the manuscript. We also thank the Geological Survey of Norway laboratories (contract 2017.0054) for treatment and preparation of samples (Ann E. Karlsen) and for carrying out the XRF analyses (Jasmin Schönenberger). Copy editing Anthony Zannino.

Funding This research is jointly funded by the Geological Survey of Norway, a postdoc grant from the University of Bergen, and the Avaldsnes Royal Manor Project at the Museum of Cultural History, University of 
Oslo. The Avaldsnes Royal Manor Project has received unnumbered grants from Karmøy Municipality and the Norwegian Ministry of Education and Research.

\section{Compliance with Ethical Standards}

Conflict of interest The authors declare that they have no conflict of interest directly or indirectly connected to this research.

Human and Animal Rights The research complies with ethical standards and does not involve human participants or animals.

Open Access This article is distributed under the terms of the Creative Commons Attribution 4.0 International License (http://creativecommons.org/licenses/by/4.0/), which permits unrestricted use, distribution, and reproduction in any medium, provided you give appropriate credit to the original author(s) and the source, provide a link to the Creative Commons license, and indicate if changes were made.

\section{References}

Arrhenius B (1985) Merovingian garnet jewellery. Emergence and social implications. Almqvist, Stockholm Ashby S (2015) What really caused the Viking Age? the social content of raiding and exploration. Archaeol Dialogues 22:89-106

Ashby S, Coutu AN, Sindbæk SM (2015) Urban networks and Arctic outlands: craft specialists and reindeer antler in Viking towns. Eur J Archaeol 18:679-704

Askvik H (1990) Petrographische Untersuchungen an Schieferwetzsteinen aus Haithabu. In: Resi HG (ed) Die Wetz- und Schleifsteine aus Haithabu. Berichte über die Ausgrabungen in Haithabu, vol 28. Karl Wacholtz Verlag, Neumünster, pp 135-142

Askvik H (2008) Whetstones from Kaupang: petrographic description and provenance. In: Resi HG, Askvik H (eds) The kaupang finds, volume III C. Whetstones and grindstones in the settlement area the 1965-1974 excavations, vol 29. Kulturhistorisk Museum, Norske Oldfunn, pp 5-17

Askvik H (2014) Petrografisk beskrivelse av skiferbrynene. In: Roesdal E, Sindbæk SM, Pedersen A (eds) Aggersborg i vikingetiden. Bebyggelsen og borgen. Jysk Arkæologisk Selskab, København, pp 303-305

Bakmark N, Rø G (2014) Jerngruver, natur- og kulturminner i nærheten av Mostadmark jernverk-Turbok. Mostadmark Jernverks Venner, Trondheim

Barrett J (2008) The Norse in Scotland. In: Brink S, Price NS (eds) The Viking world. Routledge, London, pp 411-427

Barrett J (2010) Rounding up the usual suspects. Causation and the Viking Age diaspora. In: Anderson A, Barrett JH, Boyle K (eds) The global origins and development of seafaring. McDonald Institute monographs. McDonald Institute for Archaeological Research, University of Cambridge, Cambridge, pp 289-302

Bately J (2007) Text and translation. In: Bately J, Englert A (eds) Ohthere's voyages. The Viking Ship Museum, Roskilde, pp 40-58

Bazelmans J (2009) The early-medieval use of ethnic names from classical antiquity: the case of the Frisians. In: Derks T, Roymans N (eds) Ethnic constructs in antiquity: the role of power and tradition. Amsterdam archaeological studies, vol 13. Amsterdam University Press, Amsterdam, pp 321-338

Berglund B (1995) Tjøtta-riket. En arkeologisk undersøkelse av maktforhold og sentrumsdannelser på Helgelandskysten fra Kr. f. til 1700 e. Kr. UNIT, Vitenskapsmuseet

Bos JM, Brouwer EW (2005) De kruisvormige fibulae van Friesland. Een nieuwe benadering in het onderzoek naar de herkomst van de eerste migranten vanaf AD 380/400 en de culturele oriëntatie van het Friese terpengebied tot ca. AD 550. De Vrije Fries 85:9-36

Bratrein HD, Niemi E (1994) Inn i Riket. Politisk og økonomisk integrasjon gjennom tusen år. In: Drivenes E-A, Hauan MA, Wold HA (eds) Det gjenstridige landet. Nordnorsk kulturhistorie, vol 1. Gyldendal, Oslo, pp 146-209

Buchwald VF (2005) Iron and steel in ancient times. Historisk-filosofiske Skrifter, vol 29. Det Kongelige Danske Videnskabernes Selskab, Copenhagen 
Callmer J (1991) Beads as a criterion of shifting trade and exchange connections. Studien zur Sachsenforschung 7:25-38

Callmer J (1998) Archaeological sources for the presence of Frisian agents of trade in northern Europe ca. AD 700-900. In: Wesse A (ed) Studien zur Archäologie des Ostseeraumes von der Eisenzeit zum Mittelalter. Festschrift für Michael Müller-Wille. Karl Wachholtz Verlag, Neumünster, pp $469-481$

Callmer J (2007) Urbanisation in northern and eastern Europe ca. AD 700-1100. In: Henning J (ed) The heirs of the Roman West. Post-Roman towns, trade and settlement in Europe and Byzantium, vol 1. de Gruyter, Berlin, pp 233-270

Coupland S (2002) Trading places: quentovic and Dorestad reassessed. Early Mediev Eur 11:209-232

Crosby DDB, Mitchell JG (1987) A survey of British metamorphic hone stones of the 9th to 15th centuries $\mathrm{AD}$ in the light of potassium argon and natural remanent magnetization studies. $\mathrm{J}$ Archaeol Sci 14:483-506

Curta F (2007) The amber trail in early medieval eastern Europe. In: Chazelle C, Lifshitz F (eds) Paradigms and methods in early medieval studies. Palgrave Macmillan, New York, pp 61-79

Delvaux MC (2017) Patterns of Scandinavian bead use between the Iron Age and the Viking Age ca. 600-1000 CE. Beads 29:3-30

Downham C (2011) Viking identities in Ireland: it's not all black and white. Medieval Dublin 11:185-201

Downham C (2017) The earliest Viking activity in England? Engl Hist Rev 132:1-12. https://doi. org/10.1093/ehr/cex066

Eldorhagen M (2001) Ovale spenner i Nord-Norge og Trøndelag. Stil og symbolisme i sosial sammenheng. Unpublished thesis, Troms $\emptyset$

Ellis SE (1969) The petrography and provenance of Anglo-Saxon and medieval English honestones, with notes on some other hones. Bulletin of the. Br Mus (Nat Hist) (Mineral) 2(3):135-187

Ellmers D (1985) Die Bedeutung der Friesen für die Handelsverbindungen des Ostseeraumes. In: Lindquist S-O (ed) Society and trade in the Baltic during the Viking Age. Acta Visbyensia, vol 7. Gotlands Fornsal, Visby, pp 7-54

Etchingham C (1996) Viking raids on Irish church settlements in the ninth century. A reconsideration of the annals. St Patrick's College, Maynooth

Etchingham C (2014) Names for the Vikings in Irish annals. In: Sigurdsson JV, Bolton TT (eds) CelticNorse relationships in the Irish Sea in the Middle Ages 800-1200. Brill, Leiden, pp 23-38

Fell CE (1982-3) Unfrið. An approach to a definition. Saga-Book 21:85-100

Feveile C (2006) Ribe på nordsiden af åen, 8.-12. århundrede. In: Feveile C (ed) Det ældste Ribe. Udgravninger på nordsiden af Ribe $\AA$ 1984-2000. Ribe Studier, vol 1.1. Jysk Arkæologisk Selskab, Højbjerg, pp 13-63

Feveile C, Jensen S (2000) Ribe in the 8th and 9th century. A contribution to the archaeological chronology of north western Europe. Acta Archaeol 71:9-24

Feveile C, Jensen S (2006) ASR 9 Posthuset. In: Feveile C (ed) Det ældste Ribe. Udgravninger på nordsiden af Ribe Å 1984-2000. Ribe Studier, vol 1.2. Jysk Arkæologisk Selskab, Højbjerg, pp 119-189

Frandsen LB, Jensen S (2006) ASR 7 Sct. Nicolajgade 8. In: Feveile C (ed) Det ældste Ribe. Udgravninger på nordsiden af Ribe Å 1984-2000. Ribe Studier, vol 1.2. Jysk Arkæologisk Selskab, Højbjerg, pp 9-64

Gardner A (2007) Introduction: social agency, power, and being human. In: Gardner A (ed) Agency uncovered: archaeological perspectives on social agency, power, and being human. Left Coast Press, Walnut Creek, Calif, pp 1-15

Gaunt GD (2000) The small finds. In: Mainman AJ, Rogers NSH (eds) Craft, industry and everyday life: finds from Anglo-Scandinavian York: the archaeology of York, vol 17. York Archaeological Trust, York, pp 2484-2485

Hald N (1991) The petrography of the honestones. In: Bencard M, Jørgensen LB, Madsen HB (eds) Ribe excavations 1970-76, vol 3. Sydjyske Universitetsforlag, Esbjerg, pp 142-146

Hansen G (2017) Domestic and exotic materials in early medieval Norwegian towns. An archaeological perspective on production, procurement and consumption. In: Glørstad ZT, Loftsgarden K (eds) Viking Age transformations: trade, craft and resources in western Scandinavia. Routledge, Oxford, pp 59-94

Hansen LI, Olsen B (2004) Fram til 1750. Samenes historie, vol 1. Cappelen Akademisk Forl, Oslo

Hauken ÅD (2005) The Westland cauldrons in Norway. AmS-Skrifter, vol 19. Museum of Archaeology, Stavanger

Haywood J (1999) Dark age naval power. A reassessment of Frankish and Anglo-Saxon seafaring activity. Anglo-Saxon Books, Norfolk 
Heen-Pettersen AM (2014) Insular artefacts from Viking-Age burials from mid-Norway. A review of contact between Trøndelag and Britain and Ireland. Internet Archaeol. https://doi.org/10.11141/ ia. 38.2

Hennius A, Gustavsson R, Ljungkvist J, Spindler L (2018) Whalebone gaming pieces: aspects of marine mammal exploitation in vendel and Viking Age Scandinavia. Eur J Archaeol 2018:1-20

Hines J (1984) The Scandinavian character of Anglian England in the pre-Viking period. BAR British series, vol 124. B.A.R., Oxford

Hines J (1999) Culture groups and ethnic groups in northern Germany in and around the Migration Period. Studien zur Sachsenforschung 13:219-232

Hodges R (2006) Goodbye to the Vikings? Re-reading early medieval archaeology. Duckworth, London

Holand I (2001) Sustaining life. Vessel import to Norway in the first millennium AD. AmS-skrifter, vol 17. Museet, Stavanger

Holand I (2003) Glass vessels. In: Munch GS, Johansen OS, Roesdahl E (eds) Borg in Lofoten: a chieftain's farm in north Norway: Lofotr, Vikingmuséet i Borg, Arkeologisk Skriftserie, vol 1. Tapir Academic Press, Trondheim, pp 213-229

Holberg E (2015) I høvdinganes vald. In: Holberg E, Røskaft M (eds) Håløygriket, vol 1. Fagbokforlaget, Bergen, pp 145-187

Holm O (2015) Trading in Viking-Period Scandinavia-a business only for a few? The Jämtland case. Viking Mediev Scand 11:79-126

IJssennagger NL (2013) Between Frankish and Viking: frisia and Frisians in the Viking Age. Viking Mediev Scand 9:69-98

Iversen F (2018) Emerging kingship in the 8th century? New datings of three courtyard sites in Rogaland. In: Skre D (ed) Avaldsnes-A sea-kings' manor in first-millennium western Scandinavia. Reallexikon der Germanischen Altertumskunde-Ergänzungsbände, vol 104. De Gruyter, Berlin, pp 721-746

Jansen ØJ (2001) Brynestein frå Aarekoll. In: Villand E, Årekoll N (eds) Steinbryne. Opphav-Produksjon-Bruk på slåtteteigen. Øystese, pp 22-23

Jellema D (1955) Frisian trade in the dark ages. Speculum 30:15-36

Jensen S, Feveile C (1993) Sceattasfundene fra Ribe: nogle arkæologiske kendsgerninge. By, marsk og geest 5:33-39

Jesch J (2009) Who was Wulfstan? In: Englert A, Trakadas A (eds) Wulfstan's voyage. The Viking Ship Museum, Roskilde, pp 29-36

Kars H (1983) Early-medieval Dorestad, an archeo-petrological study, Part V: the whetstones and the tochstones. Berichten van de Rijksdienst voor het Oudheidkundig Bodemonderzoek 33:1-37

Knol E, Ijssennagger N (2017) Paleography and people. Historical Frisians in an archaeological light. In: Hines J, Ijssennagger N (eds) Frisians and their North Sea neighbours: From the fifth century to the Viking Age. The Boydell Press, Woodbridge, pp 5-24

Koht H (1919) Om Haalogaland og Haaløyg-ætten. Historisk Tidsskrift 4(6):1-16

Krol T (2006) Angelsaksisch aardewerk in Noord-Nederland Nieuwe perspectieven op het Noordnederlandse kustgebied na het bewoningshiaat in de vierde eeuw. De Vrije Fries 86:9-32

Kurrild-Klitgaard P, Svensen GT (2003) Rational bandits. Plunder, public goods, and the Vikings. Public Choice 117:255-272

Lebecq S (1992) The Frisian trade in the Dark Ages: A Frisian or a Frankish/Frisian trade? In: Teksten van lezingen gehouden tijdens het symposium "Handel, handelsplaatsen en handelswaar vanaf de Vroege Middeleeuwen in de Lage Landen" te Rotterdam van 2 t/m 3 November 1990. Rotterdam Papers, vol 7. Rotterdam, pp 7-15

Lebecq S (1999) Long distance merchants and the forms of their ventures at the time of the Dorestad heyday. In: Sarfatij H, Verwers WJH, Woltering PJ (eds) In discussion with the past: archaeological studies presented to W.A. van Es. Foundation for Promoting Archaeology, Amersfoort, pp 233-238

Lindholm K-J, Ljungkvist J (2016) The bear in the grave. Exploitation of top predator and herbivore resources in first Millennium Sweden-first trends from a long-term research project. Eur J Archaeol 19:3-27

Ljungkvist J (2009) Continental imports to Scandinavia. Patterns and changes between AD 400 and 800. In: Quast D (ed) Foreigners in early medieval Europe. Monographien des Römisch-Germanischen Zentralmuseums, vol 78. Verlag des Römisch-Germanischen Zentralmuseums, Mainz, pp 27-49

Lønaas OC (2001) Brynestein i middelalderen. En analyse av brynematerialet fra Oslogate, vol 6. Universitetet i Oslo, Oslo

McLeod S (2014) The beginning of Scandinavian settlement in England. The viking 'great army' and early settlers, c. 865-900. Studies in the early Middle Ages, vol 29. Brepols, Turnhout 
Mierow CC (1915) The Gothic history of Jordanes in English version. Speculum Historiale, Cambridge

Mitchell JG, Askvik H (1984) Resi HG (1984) Potassium-argon ages of schist honestones from the Viking Age sites at Kaupang (Norway), Aggersborg (Denmark), Hedeby (West Germany) and Wolin (Poland), and their archaeological implications. J Archaeol Sci 11:171-176

Moore DT (1978) The petrography and archaeology of English honestones. J Archaeol Sci 5:61-73

Moore DT (1983) Petrological aspects of some sharpening stones, touchstones, and milling stones. In: Kempe DRC, Harvey AP (eds) The petrology of archaeological artefacts. Clarendon Press, Oxford, pp 277-300

Myhre B (1992) The royal cemetery at Borre, Vestfold: A Norwegian centre in a European periphery. In: Carver M (ed) The age of Sutton Hoo: The seventh century in North-West Europe. Boydell Press, Woodbridge, pp 301-314

Myhre B (1993) The beginning of the Viking Age—some current archaeological problems. In: Faulkes A, Perkins R (eds) Viking revaluations. Viking Society for Northern Research, University College London, London, pp 183-204

Myrvoll S (1991) The hones. In: Bencard M, Jørgensen LB, Brinch MH (eds) Ribe excavations 1970-76, vol 3. Sydjysk Universitetsforlag, Esbjerg, pp 115-141

Näsman U (1986) Vendel Period glass from Eketorp-II, Öland, Sweden: on glass and trade from the late 6th to the late 8th centuries AD. Acta Archaeol 55:55-116

Näsman U (1991) Sea trade during the Scandinavian Iron Age: Its character, commodities, and routes. In: Crumlin-Pedersen O (ed) Aspects of maritime Scandinavia AD 200-1200. Proceedings of the Nordic Seminar on Maritime Aspects of Archaeology, Roskilde, 13th-15th March 1989. The Viking Ship Museum, Roskilde, pp 23-40

Näsman U (2000) Exchange and politics: the eighth-early ninth century in Denmark. In: Hansen IL, Wickham $\mathrm{C}$ (eds) The long eighth century: production, distribution and demand: the transformation of the Roman world, vol 11. Brill, Leiden, pp 35-68

Näsman U (2003) Beads of amber, carnelian, glass, jet, rock-crystal and stone. In: Munch GS, Johansen OS, Roesdahl E (eds) Borg in Lofoten: a chieftain's farm in north Norway. Lofotr, Vikingmuséet i Borg, Arkeologisk Skriftserie, vol 1. Tapir Academic Press, Trondheim, pp 213-240

Nelson JL (1997) The frankish empire. In: Sawyer P (ed) The Oxford illustrated history of the Vikings. Oxford University Press, Oxford, pp 19-47

Nicolay J (2005) Nieuwe bewoners van het terpengebied en hun rol bij de opkomst van Fries koningschap: de betekenis van gouden bracteaten en bracteaatachtige hangers uit Friesland (vijfde-zevende eeuw na Chr.). De Vrije Fries 85:37-103

Nicolay J (2017) Power and identity in the southern North Sea area: the migration and merovingian periods. In: Hines J, Ijssennagger N (eds) Frisians and their North Sea neighbours: from the fifth century to the Viking Age. The Boydell Press, Woodbridge, pp 75-92

Nilsen G (2016) Marine mammal train oil production methods: experimental reconstructions of Norwegian Iron Age slab-lined pits. J Marit Archaeol 11:197-217

Ó Corráin D (1998) Vikings in Ireland and Scotland in the ninth century. Peritia 12:296-339

Ó Corráin D (2008) The Vikings in Ireland. In: Brink S, Price NS (eds) The Viking world. Routledge, London, pp 428-433

Oftedahl C (1980) Geology of Norway. NGU 356:3-114

Pilø L (2011) Things from the town: artefacts and inhabitants in Viking-Age Kaupang. Norske oldfunn. In: Skre D (ed) The Pottery, vol 24. Aarhus University Press, Århus, pp 281-304

Price N (2002) The Viking way. Religion and war in late Iron Age Scandinavia. Aun, vol 31. Department of Archaeology and Ancient History, Uppsala

Price N (2014) Ship-men and slaughter-wolves: pirate polities in the Viking Age. In: Amirell SE, Müller L (eds) Persistent piracy: maritime violence and state-formation in global historical perspective. Palgrave Macmillan, Basingstoke, pp 51-68

Price N (2016) Pirates of the north sea? The Viking ship as political space. In: Melheim L, Glørstad H, Glørstad AZT (eds) Comparative perspectives on past colonisation, maritime interaction and cultural integration. Equinox, Sheffield, pp 149-176

Raffield B, Price N, Collard M (2017) Male-biased operational sex ratios and the Viking phenomenon. An evolutionary anthropological perspective on late Iron Age Scandinavian raiding. Evol Hum Behav 38:315-324

Resi HG (1990) Die Wetz- und Schleifsteine aus Haithabu. Berichte über die Ausgrabungen in Haithabu, vol 28. Karl Wachholtz Verlag, Neunmünster

Resi HG (2008) Whetstones and grindstones used in everyday life at Kaupang. In: Askvik H, Resi HG (eds) Whetstones and grindstones in the settlement area: The 1965-1974 excavations, vol 29. Norske Oldfunn, Olso, pp 19-149 
Resi HG (2011) Whetstones, grindstones, touchstones and smoothers. In: Skre D (ed) Things from the town: Artefacts and inhabitants in Viking-age Kaupang. Norske Oldfunn, vol 24. Aarhus Universitetsforlag, Aarhus, pp 373-393

Roesdahl E (1995) Hvalrostand, elfenben og nordboerne i Grønland. Odense universitetsforlag, Odense

Roesdahl E (2005) Walrus ivory-demand, supply, workshops, and Greenland. In: Mortensen A, Arge SV (eds) Viking and Norse in the North Atlantic: annales societatis scientiarum færoensis: supplementa, vol 44. Føroya Froðskaparfelag, Tórshavn, pp 182-191

Røstad IM (2016) Smykkenes språk: Smykker og identitetsforhandlinger i Skandinavia ca. 400-650/700 e.Kr. Universitetet i Oslo, Oslo

Schreiner J (1928) Trøndelag og rikssamlingen. Avhandlinger, vol 1928 no. 3. Det Norske videnskapsakademi, Oslo

Sheehan J (2008) The longphort in Viking Age Ireland. Acta Archaeologica 79:282-295

Simek R (2004) The emergence of the Viking Age: reasons and triggers. In: Simek R, Engel U (eds) Vikings on the Rhine: recent research on early medieval relations between the Rhinelands and Scandinavia: studia medievalia septentrionalia, vol 11. Fassbaender, Wien, pp 9-22

Sindbæk SM (2011) Silver economies and social ties: long-distance interaction, long-term investments - and why the Viking Age happened. In: Graham-Campbell J, Sindbæk SM, Williams G (eds) Silver economies, monetisation and society in Scandinavia, AD 800-1100. Aarhus University Press, Aarhus, pp 41-65

Sindbæk SM (2017) Urbanism and exchange in the North Atlantic/Baltic, 600-1000 CE. In: Hodos T (ed) The Routledge handbook of archaeology and globalization. Routledge, London, pp 553-565

Sitzmann A, Grünzweig FE (2008) Die Altgermanischen Ethnonyme: Ein handbuch zu ihrer Etymologie: Philologica Germanica, vol 29. Fassbaender, Wien

Sjøvold T (1974) Late Iron Age (Merovingian and Viking periods). The Iron Age settlement of Arctic Norway: a study in the expansion of European Iron Age culture within the Arctic Circle, vol 2. Universitetsforlaget, Troms $\varnothing$

Skre D (2011a) The inhabitants: origins and trading connexions. In: Skre D (ed) Things from the town: Artefacts and inhabitants in Viking-age Kaupang: Norske Oldfunn, vol 24. Aarhus Universitetsforlag, Aarhus, pp 417-441

Skre D (2011b) Kaupang: Between East and West; between North and South. In: Skre D (ed) Things from the town: Artefacts and inhabitants in Viking-age Kaupang. Norske Oldfunn, vol 24. Aarhus Universitetsforlag, Aarhus, pp 443-449

Skre D (2018a) Aristocratic presence along the Karmsund Strait 2000 BC-AD 1368. In: Skre D (ed) Avaldsnes-a sea-kings' manor in first-millennium western Scandinavia: Reallexikon der Germanischen Altertumskunde-Ergänzungsbände, vol 104. De Gruyter, Berlin, pp 749-764

Skre D (2018b) Sea kings on the Norðvegr. In: Skre D (ed) Avaldsnes-A sea-kings' manor in firstmillennium western Scandinavia: Reallexikon der Germanischen Altertumskunde-Ergänzungsbände, vol 104. De Gruyter, Berlin, pp 781-799

Skre D (2018c) Viking-age economic transformations. The West-Scandinavian Case. In: Glørstad ZT, Loftsgarden K (eds) Viking age transformations: trade, craft and resources in western Scandinavia. Routledge, Oxford, pp 1-27

Sode T, Gratuze B, Lankton JW (2017) Red and orange high-alumina glass beads in 7th and 8th century Scandinavia: Evidence for long distance trade and local fabrication. In: Wolf S, Pury-Gysel AD (eds) Annales du 20e congrés de l'Association Internationale pour l'Histoire du Verre. Verlag Marie Leidorf, Rahden, pp 326-333

Stenvik L (1997) lron production in mid-Norway: an answer to local demand? Studien zur Sachsenforschung 10:253-263

Storli I (2006) Hålogaland før rikssamlingen. Politiske prosesser i perioden 200-900 e.Kr. Instituttet for sammenlignende kulturforskning, Serie B, Skrifter, vol 123. Novus forlag, Oslo

Stylegar F-A, Bonde N (2016) Between Sutton Hoo and Oseberg: dendrochronology and the origins of the ship burial tradition. Dan J Archaeol 2016:1-15

Svennung J (1967) Jordanes und Scandia: Kritisch-exegetische Studien. Kungl. humanistiska vetenskapssamfundet i Uppsala Skrifter, vol 44. Almquist \& Wiksell, Stockholm, Uppsala

Verhulst A (2002) The Carolingian economy. Cambridge University Press, Cambridge

Vierck H (1983) Ein Schmiedeplatz aus Alt-Ladoga und der präurbane Handel zur Ostsee vor der Wikingerzeit. Münstersche Beiträge zur antiken Handelsgeschichte 2:3-64

Vinsrygg S (1979) Merovingartid i Nord-Noreg: Arkeologiske avhandlinger, vol 2. Universitetet i Bergen, Bergen, Historisk museum 
Walther S (2004) The Vikings in the Rhinelands according to Latin sources. In: Simek R, Engel U (eds) Vikings on the Rhine. Recent research on early medieval relations between the Rhinelands and Scandinavia. Studia Medievalia Septentrionalia, vol 11. Fassbaender, Wien, pp 165-177

Wamers E (1985) Insularer Metallschmuck in wikingerzeitlichen Gräbern Nordeuropas. Untersuchungen zur skandinavischen Westexpansion. Offa-Bücher, vol 56. Karl Wachholtz Verlag, Neumünster

Wamers E (2011) Continental and insular metalwork. In: Skre D (ed) Things from the town: Artefacts and inhabitants in Viking-Age Kaupang. Kaupang excavation project Publication Series, vol 3. Aarhus University Press, Århus, pp 65-97

Wickham C (2008) Rethinking the structure of the early medieval cconomy. In: Davis JR, McCormick M (eds) The long morning of medieval Europe. Routledge, London

Williams G (2008) Raiding and Warfare. In: Brink S, Price NS (eds) The Viking world. Routledge, London, pp 193-203

Wilson D (1985) Trade between England and Scandinavia and the Continent. In: Düwel K, Jankuhn H, Siems H, Timpe D (eds) Der Handel des frühen Mittelalters. Untersuchungen zu Handel und Verkehr der vor- und frühgeschichtlichen Zeit in Mittel- und Nordeuropa, vol 3. Vandenhoeck \& Ruprecht, Göttingen, pp 255-269

Wood I (1983) The Merovingian North Sea. Occasional papers in medieval topics, vol 1. Viktoria, Alingsås

Publisher's Note Springer Nature remains neutral with regard to jurisdictional claims in published maps and institutional affiliations. 